\title{
"The long wish'd for object" — Opening the Trade to Japan, 1785-1795
}

\section{Robert J. King}

Une des raisons d'établir une colonie anglaise en Nouvelle-Galles du Sud en 1788 était de soutenir une tentative d'employer les fourrures de la côte du nord-ouest de l'Amérique pour ouvrir le commerce avec le Japon. Pendant la décennie 1785-1795, des négociants britanniques encouragés par le président de la Société Royale, Sir Joseph Banks, et appuyés par leur gouvernement, ont fait une tentative soutenue de développer ce commerce. Ces espoirs et efforts ont échoué face à l'opposition d'une Espagne déterminée à défendre ses réclamations bien antérieures au territoire et à la navigation dans le Pacifique nord et aussi d'un Japon tenant obstinément à un isolement national.

\section{The Voyage of the Lady Penrhyn}

Reporting on the successful establishment of the Botany Bay settlement on 28 March 1789, the London press informed its readers in relation to one of the ships of the First Fleet which had transported the convicts to New South Wales: "The Lady Penrhyn sailed to the north west coast of America, on the fur trade." A subsequent press report stated:

By the Talbot East-Indiaman there is advice, that the ship which sailed from Botany Bay to the North-West coast of America, on the fur trade, had a few days after her arrival on the coast sprung a leak, and was otherwise so much disabled as to be obliged to proceed to Otaheite; that on her arrival there her bottom was found to be so bad and unfit to combat the ice, that she sailed for China, where she had arrived before the Talbot sailed. ${ }^{2}$

The Lady Penrhyn sailed on from Port Jackson on 5 May 1788 under a contract with George Mackenzie McCaulay, an alderman of the City of London, to go to the "North West Coast of America to Trade for furrs \& after that to proceed to China \& barter the Furrs

1 The London Chronicle, The Whitehall Evening Post, 28 March; The Bath Chronicle, 2 April; Mercure de France, 25 avril 1789.

2 The London Chronicle, 30 April; The Whitehall Evening Post and The Times, 2 May; Gazette de France, 12 mai; Mercure de France, 16 mai 1789.

The Northern Mariner/le marin du nord, XX No. 1, (January 2010), 1-34 
\&ca for Teas or other such Goods . . ."3 Her owners, Timothy and William Curtis (merchants and, in William's case, like McCaulay, a London alderman), had obtained a license to sail to the North West coast from the South Sea Company, which still maintained its ancient monopoly rights over British trade to the eastern Pacific. ${ }^{4}$ The poor condition of the ship and sickness among her crew compelled the Lady Penrhyn to turn back from this voyage when she had gone only as far as Tahiti and not, as reported in the newspapers, as far as the American coast. Arthur Bowes Smythe, the Lady Penrhyn's surgeon, recorded in his journal for 3 July 1788, before the vessel reached Tahiti: "This day some disagreement happn'd betwixt the Capt. \& Mr. W: [Watts, the supercargo] respectg. going to the N.W. as the Ship's Co. were in so deplorable a situation — The Capt. Declared the Charter void." 5 The voyage is commemorated in the names of Curtis and Macaulay (now Macauley) Islands, in the Kermadec Group, and Penrhyn Island (Tongareva) in the Northern Cooks.

\section{New South Wales and Trade with Japan}

The voyage of the Lady Penrhyn was an attempt to put into execution one of the reasons given for founding the Botany Bay colony, namely, to use the colony as a base to develop the fur trade of the North West Coast of America, and for trade with China, Korea and Japan. ${ }^{6}$ A number of advantages to be expected from a colony were put forward in the "Proposal for establishing a Settlement in New South Wales" drawn up by James Matra under the guidance of Sir Joseph Banks in August 1783. Matra had visited Botany Bay with Banks in 1770 on James Cook's Endeavour voyage. He had served on the ship as a junior officer but in 1783 as an American Loyalist found himself in London as a "Solitary fugitive" (refugee in modern parlance) and, like many of his fellow Loyalists, in search of a new home, perhaps in a new colony. He approached Banks on 28 July requesting to be allowed to participate in Banks's plan for a settlement in the South Seas. ${ }^{7}$ A position was

3 Arthur Bowes Smythe, "A Voyage to Botany Bay \& Oteheite, 1787, by A.B.S. Surgeon, Lady Penrhyn," National Library of Australia, MS 4568. Cf. G. Fidlon and R.J. Ryan, eds., The Journal of Arthur Bowes Smyth: Surgeon, Lady Penrhyn, 1787-1789 (Sydney: Australian Documents Library, 1979), 86.

4 South Sea Company Court of Directors Minutes, 8 and 10 March 1787, South Sea Company Papers, British Library, Additional MS 25,521; cited in Edouard A. Stackpole, Whales and Destiny (Amherst: U. Mass., 1972), 118.

5 Smythe, "Voyage"; Fidlon and Ryan, Journal.

6 Margaret Steven, Trade, Tactics and Territory (Melbourne: Melbourne UP, 1983), chapter 6, “'So Very Undigested and Very Expensive a Scheme': New South Wales"; O.H.K. Spate, Paradise Found and Lost (Sydney: ANU Press, 1988), chapter 13, "Botany Bay and Nootka Sound," and Barry M. Gough, The Northwest Coast: British Navigation, Trade, and Discoveries to 1812 (Vancouver: UBC Press, 1992), chapter 7, "Botany Bay and Nootka Sound", have discussed the complementarity of the British settlement of New South Wales and the exploitation of the resources of the North West Coast of America. This article reemphasizes the enthusiasm Banks and his circle felt at this time for Japan, and their attempt use the furs of the North West Coast to gain entry to Japan.

7 Matra to Banks, 28 July 1783, British Library, Add. Ms. 33979, f. 206; photoduplicated in 
found for him at the Plantation Office (an adjunct of the Home Office), and by 23 August (that is, less than three weeks later) he had produced his proposal with a fully developed set of reasons for a colony composed of American Loyalists, Chinese and South Sea Islanders (but not, at this stage, convicts). Matra wrote: "Sir Joseph Banks highly approves of the Settlement, \& is very ready to give his opinion of it, either to His Majesty's Ministers, or others, whenever they may pleased to require it." In fact, only Banks had the information at his disposal to allow the preparation of Matra's memorial within so short a space of time (there is no evidence that Matra had thought in detail about Botany Bay prior to 28 July), and Banks evidently used Matra as an indirect means of putting forward his ideas publicly. ${ }^{8}$ Following an interview with Secretary of State Lord Sydney in March 1784, Matra amended his proposal to include convicts as settlers. ${ }^{9}$ Matra's plan can be seen to have "provided the original blueprint for settlement in New South Wales." 10 A cabinet memorandum of December 1784 shows the government had Matra's plan in mind when considering the erection of a settlement in New South Wales. ${ }^{11}$ The government also incorporated into the colonization plan the project for settling Norfolk Island, with its attractions of timber and flax, proposed by Banks's Royal Society colleagues, Sir John Call and Sir George Young. ${ }^{12}$ Matra's proposal contained a passage which indicated the enthusiasm Banks and his circle had developed for opening trade with Japan, and for using the North Pacific fur trade for this purpose:

The Aleutian \& Foxes Islands, situated between Asia \& America, \& the Kuril Islands, which abound with the choicest Furs, lie nearly North of New South Wales. It is from these

Alan Frost, The Precarious Life of James Mario Matra: Voyager with Cook; American Loyalist; Servant of Empire (Melbourne: Miegunyah, 1995), 114.

8 Harold B. Carter, "Banks, Cook and the 18th Century Natural History Tradition," Tony Delamotte and Carl Bridge, eds., Interpreting Australia: British Perceptions of Australia since 1788 (London: Sir Robert Menzies Centre for Australian Studies, 1988), 4-23.

9 Matra to Fox, 2 April 1784, British Museum, Add. Ms 47568.

10 Alan Atkinson, "The first plans for governing New South Wales, 1786-87," Australian Historical Studies 24, no. 94 (April 1990), 31.

11 "Memo. of matters to be brought before Cabinet", State Library of New South Wales, Dixon Library Add. MS Q522; cited in Atkinson (1990), 31, dated and photoduplicated in Alan Frost, "Historians, Handling Documents, Transgressions and Transportable Offences," Australian Historical Studies 25, no.98 (Oct.1992), 208-9. See also John Gascoigne, Science in the Service of Empire: Joseph Banks, the British State and the Uses of Science in the Age of Revolution (Melbourne: Cambridge University Press, 1998), 187. David Mackay argued in A Place of Exile: The European Settlement of New South Wales (Melbourne: Oxford UP, 1985), 37, that there was "no evidence that Matra, Call or Young were in fact consulted directly by government after their evidence before the Beauchamp Committee" and that it was "highly misleading to draw any conclusions about government intentions from the private plans of these private individuals," but the Cabinet memorandum of December 1784 recovered by Atkinson and discussed by Frost shows that Matra's plan formed the basis for the scheme of colonization adopted by the Government in August 1786. He was credited with being "the projector of the Botany Bay settlement" in The Morning Post, 14 April 1789.

12 Robert J. King, "Norfolk Island: Phantasy and Reality, 1770-1814," The Great Circle 25, no. 2 (2003), 20-41. 
Islands the Russians get the most $\&$ best of their Furs, with which they carry on a very lucrative Trade, by Land with the Chinese. Our Ships that sailed under the Command of Caps. Cooke \& Clerke stopped at some of them, \& the Skins which they procured there, sold in China, at 400 hard Dollars each, though for the few they brought home, of the same quality, they only received about Ten Pounds each. As our situation in New South Wales would enable us to carry on this Trade, with the utmost facility, we should no longer be under the necessity of sending such immense quantities of Silver, for the different Articles we import from the Chinese Empire. There is also a prospect of considerably extending our Woollen Trade. We know that large quantities of woollen Cloth, are smuggled to Japan by the Russians, which as it is taken by land Carriage from St. Petersburgh to Kamschatka, and then to the Islands, by a very precarious Navigation in Boats must be extremely dear; the Japanese however, go in their Junks to the Islands \& purchase great quantities of it. ${ }^{13}$

This passage was published in an article in The General Advertiser of 13 October 1786, one of a series consisting largely of extracts from James Matra's proposal explaining the reasons for establishing the colony. ${ }^{14}$

John Call, member of Parliament and fellow of the Royal Society, and former chief engineer of the East India Company, who also played a significant role with Banks in promoting the colonisation of New South Wales, wrote in a letter dated 3 September 1784 to Warren Hastings, governor-general of Bengal: "I have lately suggested to the Ministry the sending of our Criminals to an Establishment on New South Wales, or on New Zealand, which I have long thought might be form'd with future Views to share largely in the Trade of Chili \& Peru - I have also an Idea that a very advantageous Trade might be open'd with the North West part of North America about Cookes River." 15 This idea was also expressed in An Historical Narrative of the Discovery of New Holland and New South Wales, published by Banks's friend, John Stockdale, in 1786 to explain the reasons for the settlement at Botany Bay:

The importance of Botany-bay will appear by all who examine Capt. Cook's chart of his discoveries, where they will find there is an open sea from the bay to a cluster of islands called New-Zealand, lying somewhat to the southward of the east, at the distance of about four hundred leagues. At about the same distance from the north-east, lye the New Hebrides, at a very moderate distance from them; under the same degree of latitude are the Friendly Islands, the Society Islands, and the Marquesas Isles. From these latter the run to the Sandwich Islands does not exceed eight [hundred] leagues; so that this whole tour scarcely equals a voyage from Great-Britain to the Carribee Islands, and back. Its situation is well adapted for carrying on a trade between Nootka-Sound and Cook's River, on the American coast, and the Islands of Japan and the Chinese Empire, in sea-otter skins; as also to perfect the discoveries made in that part of the globe, a matter which the late Captain King had much at heart. ${ }^{16}$

13 National Archives (Kew), CO 201/1, ff. 57-61; British Library, Add. MS 47568, ff. 240-6.

14 The General Advertiser, 12, 13, 17 and 14 October 1786.

15 Call to Hastings, 3 September 1784, Add. MS 29166: 27-8, National Library of Australia mfm AJCP M2672; quoted in Alan Frost, Convicts \& Empire: A Naval Question, 1776-1811 (Melbourne: Oxford UP, 1980), 23, 203.

16 An Historical Narrative of the Discovery of New Holland and New South Wales (London, 


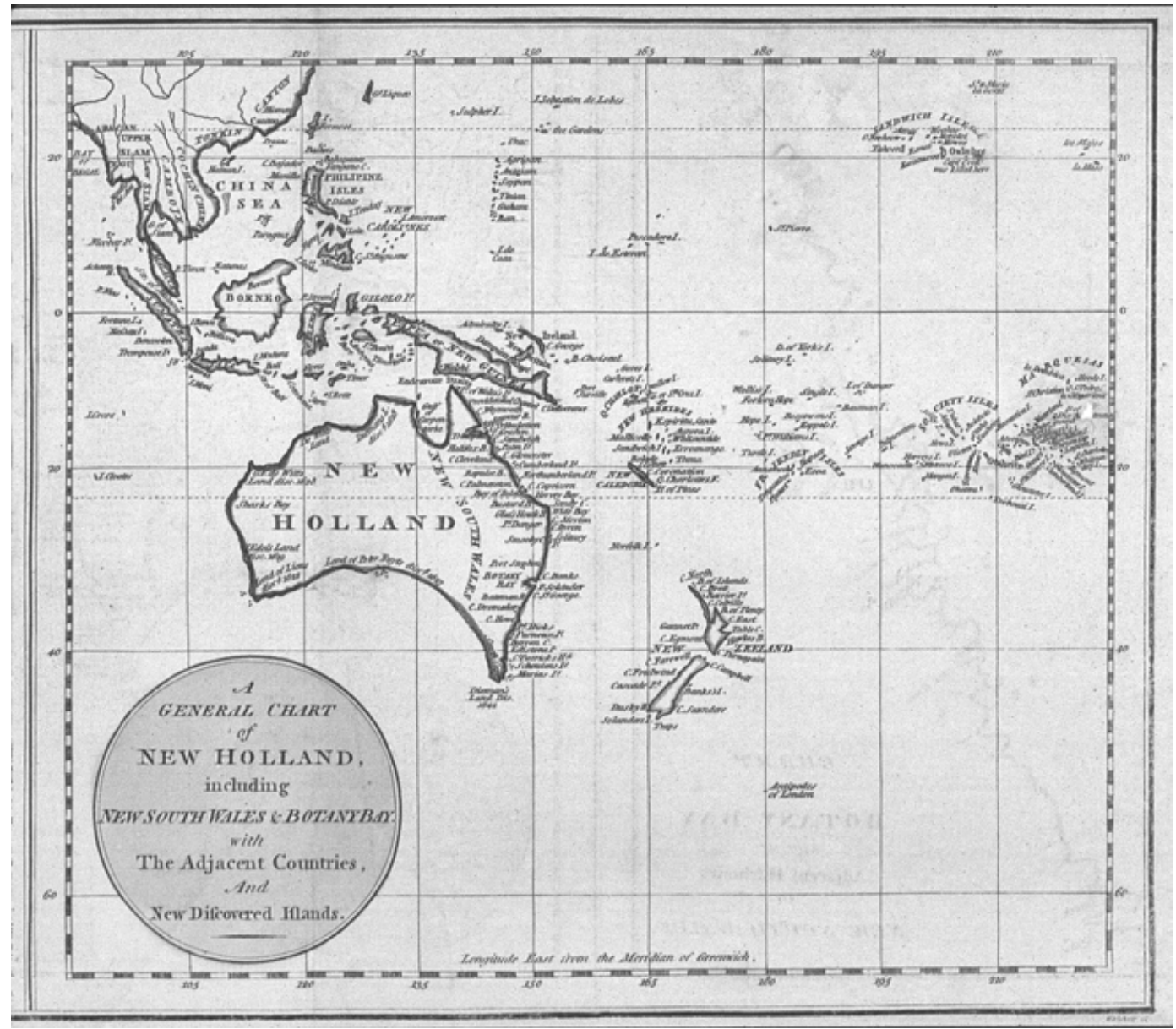

Illustration 1: A General Chart of New Holland including New South Wales \& Botany Bay with The Adjacent Countries and New Discovered Lands, published in An Historical Narrative of the Discovery of New Holland and New South Wales, London, Fielding and Stockdale, November 1786. Courtesy of the National Library of Australia.

This passage was quoted in the General Evening Post of 16 November 1786. The Historical Narrative illustrated this description with "A General Chart of New Holland, including New South Wales \& Botany Bay, with The Adjacent Countries, and New Discovered Islands." A similar chart was published in the February 1787 issue of The

Stockdale, 1786), 53. This work was quite possibly drafted by George Chalmers, Matra's fellow Loyalist and employee at the Plantations Office, who is known to have done similar editorial work for Banks and Stockdale on other occasions: see H.B. Carter, Sir Joseph Banks (London: British Museum-Natural History, 1988), 174-5. On Banks and Stockdale, see also Eric Stockdale, T'is treason, my good man! Four Revolutionary Presidents and a Piccadilly Bookshop (New Castle, Del.: Oak Knoll Press, 2005), 261-2; and Nathan Garvey, "Selling a penal colony: the booksellers and Botany Bay," Script and Print 31, no. 1 (2007), 20-38. 
Political Magazine, with the difference being that this chart extended to latitude $50^{\circ} \mathrm{N}$, and so included Japan, the Kurile Islands and the North West coast of America. All the island groups indicated (somewhat inaccurately) in the Historical Narrative's chart were included, together with that portion of the continent of Australia eastward of the meridian of $135^{\circ}$ East, in the territorial claim embodied in the proclamation of the colony by its first governor, Arthur Phillip, on 7 February 1788 at Port Jackson. ${ }^{17}$ Both charts demonstrated the essential imperial interests the British government had in founding the colony. ${ }^{18}$

The directors of the East India Company asked their inspector of sea journals, Alexander Dalrymple, for an opinion on the proposed colony in July 1785. Dalrymple attacked the proposal as a subterfuge for getting around the company's charter of exclusive trade in the Pacific: "the true prospects of the Undertakers," were "to carry on an illicit Trade under pretext of a Colony." In the letter he sent to the directors of the East India Company on 13 July 1785 detailing his opposition to the proposal, Dalrymple listed all the reasons given in Matra's proposal to support its advantages, including, "for carrying on the Fur-Trade to the NW Coast of America." Dalrymple ridiculed the idea: "The Prosecution of the Fur-Trade to the NW Coast of America from this proposed settlement, which has no particular advantage of situation for that purpose, I considered merely as a Tub to the Whale, for that Trade will probably be exhausted, or find another Channel, before a voyage thither could be fitted out from such an infant Settlement." After the government announced in September 1786 that it would proceed with the colony, Dalrymple's opinion was published under the title, A Serious Admonition to the Publick on the Intended Thief Colony at Botany Bay. ${ }^{19}$ The company continued to be seen to be hostile to the colony: an article in the Morning Star of 1 May 1789 declared that "the jealousy of the East India Company" would frustrate hopes for trade with China and Japan from the Botany Bay

17 The extent of this territorial claim excited the amazement of many when they first learned of it. "Extent of Empire demands grandeur of design," wrote Watkin Tench in A Narrative of the Expedition to Botany Bay (London: Debrett, 1789), 103. "Truly an astonishing extent!" remarked the Dutch translator of Tench's book, who went on to say: "The outermost or easternmost of the Marquesas Islands lie, even according to the English maps, at least eightyfive degrees eastward of the line where they place the commencement of the Territory of New South Wales. They have therefore formed a single province which, beyond all doubt, is the largest on the whole surface of the earth. From their definition it covers, in its greatest extent from East to West, virtually a fourth of the whole circumference of the Globe," Beschrijving van den Togt Naar Botany-Baaij... door den Kapitein Watkin Tench (Amsterdam: Martinus de Bruijn, 1789), 211.

18 The status of these charts as representing the position of the government regarding the territory claimed for the New South Wales colony is discussed in Robert J. King, "Terra Australis, New Holland and New South Wales: the Treaty of Tordesillas and Australia," The Globe no. 47 (1998), 35-55.

19 Alexander Dalrymple, A Serious Admonition to the Publick on the Intended Thief Colony at Botany Bay (London: Sewell, October 1786), 22-5. 
settlement. $^{20}$

On 24 August 1791, Timothy and William Curtis advised the East India Company they were fitting out two ships and a cutter for the North West coast of America, and requested a licence for one of their ships and the cutter, which afterwards would proceed to China with whatever they had taken or purchased. They were willing to enter into a bond that they would not transport any European articles to China, or return to Europe with any merchandise that was the produce of China. ${ }^{21}$ These ships were the Butterworth, William Brown, the Jackal, Alexander Stewart (or Stuart) and the Prince Lee Boo, Captain Sharp, and were acknowledged as being owned by "a company of London merchants, the principal of which is Alderman Curtis." 22 The so-called Butterworth squadron operated on the North West Coast in 1792, 1793 and 1794 under the overall command of William Brown, but did not make use of Port Jackson, making their passage by way of Cape Horn and the Marquesas. ${ }^{23}$ The failure of the Lady Penrhyn venture was a setback for those who wished to use the New South Wales colony as a base for voyages to the North West Coast to exploit the fur trade and it was several years before ships engaged in this trade again used Port Jackson, starting with the Boston fur trader Fairy in October $1793 .^{24}$

\section{The Etches Venture}

The Botany Bay project was complemented by the official encouragement given to the consortium of merchants headed by Richard Cadman Etches, which was also designed to exploit the fur trade of the North West coast of America to develop trade with Japan. He, his brother John Etches, Nathaniel Portlock, George Dixon, and four others formed the King George's Sound Company, otherwise known as Richard Cadman Etches \& Company. George Dixon and Nathaniel Portlock were veterans of Cook's voyage to the North West coast, and from late 1782 to late 1784 Dixon had been closely involved with an attempt to send an expedition to the North West coast under the Imperial (Austrian) flag. When this attempt failed, Dixon approached Banks in August 1784 with a proposal to lead an expedition overland from eastern Canada to the North West coast.

20 See the comment by M.C. Sprengel: "The East India Company to some extent finds the right of the British Government to send felons to New Holland contestable because of their having the sole privilege to make voyages to the lands between the Cape of Good Hope and the Streights of Magellan," Allgemeines historisches Taschenbuch (Berlin, 1787), 8.

21 British Library, India Office Records and Archives, Court Minutes, 1791.

22 F.W. Howay, A List of Trading Vessels in Maritime Fur Trade, 1785 -1794 (Ottawa: Royal Society of Canada, 1930), 123, 126, 127, 129. Robert Galois, ed., A Voyage to the North West Side of America: The Journals of James Colnett, 1786-89 (Vancouver: UBC Press, 2004), 326, n. 441.

23 Douglas Cole, "Sigismund Bacstrom's Northwest Coast Drawings and an Account of his Curious Career," BC Studies XLVI (Summer 1980), 61-86, 64-65. See also Robin Inglis, Historical Dictionary of the Discovery and Exploration of the Northwest Coast of America (Lanham, MD: Scarecrow Press, 2008), 52-3.

24 J.S. Cumpston, Shipping Arrivals and Departures, Sydney, 1788-1825 (Canberra: Roebuck Society, 1977), 28. 
Banks declined to support this proposal but put him in contact with Etches, a shipping merchant, with a view to putting into effect a version of the Austrian plan.

On 13 March 1785 Etches discussed the formation of the venture with Banks, and was persuaded by him to expand the objectives from simple trade between the North West coast and Canton to an attempt to open trade with Japan, as he acknowledged the following day in writing:

Sensible of the high honour done us yesterday by your kind offer of assistance for the maturing of our plan - and how highly important your opinion and advice must be to us, from your intimate knowledge of the parts to which our attempt will be directed - from the great encouragement you was pleas'd to give us respecting the prospect of opening a friendly Commerce with the Japanese - and from the knowledge you was pleas'd to say you cou'd procure from your friend who had made the tour of those Islands, this kind communication Sir we hold in the most valuable and flattering point of View - which not only enlarges our Present scale of the Undertaking in the most extreme degree but holds out to us a much greater degree of certainty than we cou'd conceive... Thus, Sir, our Views from your generous patronage are raised to a degree of magnitude we had not before conceiv'd. $^{25}$

Banks had developed an interest in Japan following the visit to London in December 1778 of the Swedish botanist, Carl Thunberg, who had spent the period August 1775 to December 1776 in Japan as physician to the Dutch merchants at Dejima (the tiny islet in Nagasaki bay to which the Dutch trade factory was confined). Despite the restrictions which the Japanese government placed on Dutch movements, Thunberg had learned Japanese and had opportunity to examine the country and collect plants. He had also accompanied the Dutch factory captain on a journey to Edo for an audience with the Shogun. He had observed a new openness on the part of the Japanese toward foreigners, and had come away from the country convinced that it would soon relax its strict seclusion policy. In London, Thunberg was introduced to Banks by his compatriot (and Banks's librarian) Jonas Dryander. A letter from Thunberg to Banks was read at a meeting of the Royal Society on 10 February 1780, and published in Philosophical Transactions in Swedish, with an English translation, "Translation of a short Extract from a Journal kept by C.P. Thunberg, M.D. during his Voyage to, and Residence in, the Empire of Japan, in a letter addressed to the President." 26 His views on the fur trade were referred to in a London newspaper of 12 October 1785: "Dr. Thuenburg says, in so high estimation are the

Etches to Banks, 14 March 1785, Kew Herbarium Library, Banks Correspondence, Vol.I, no. 195.

26 C. Thunberg, "Ett kort utdrag af en Journal, hållen pår en resa til och uti Kejsaredömet Japan, gjord af Doctor Thunberg åren 1775 och 1776, skrifvit til Herr Joseph Banks, Præses uti Royal Society, i London," Philosophical Transactions LVXX, pt. 1 (1780, Part I), 143-56, appendix, i-viii, noticed in The Gentleman's Magazine (October 1780); idem., "Observations on the Manners, Customs, Dress, Agriculture, \&c. of the Japanese," The European Magazine, (April 1786), 233-8, (May 1786), 313-6, (June 1786), 401-4; and Travels in Europe, Africa and Asia (London, 1795). Carl Steenstrup, "A Gustavian Swede in Tanuma Okitsugu's Japan,” Journal of Intercultural Studies VI (1979), 20-43. 
Sea Otter skins held in Japan, that he hath known them to sell from 250 to 500, nay, even 600 dollars per skin."27 From his conversations with Thunberg, Banks believed that the Japanese market might be opened to British traders. ${ }^{28}$

Banks promised Etches he would write to Thunberg in Uppsala to obtain further information, which he did in a letter dated 17 June 1785:

Some Merchants here are employd in fitting out Ships for the Purpose of Trading with the natives of the $\mathrm{N}: \mathrm{W}$ : Coast of America for their valuable furs. They wish to attempt a trade with the natives of Japan. I think I have heard you say that the Government of Japan is so circumstancd that it is probable ships who applied to the northern Provinces which are independent of the Emperor might be receivd and admitted to trade. You would confer an Obligation of importance upon me if you would write me a letter explaining your Sentiments on that head Fully... Be so good as to send an answer to the Part of my Letter which referrd to a trade with Japan as soon as you can conveniently. ${ }^{29}$

The prime object of the venture of the Etches consortium, the King George's Sound Company, was made clear in the "Additional Proposals" attached to their application for a license from the East India Company: "The Japanese Islands would be our grand object, to open a friendly intercourse with which, we have every possible hope of attaining from holding out so great a temptation as the Sea Otter Skins, which being held in such high estimation by them, we persuade ourselves it will not only do away the prejudice of Europe in general 'that the Japanese will not admit of an European commerce, except with the Dutch, and that in a very limited degree' but will open a new source of Commerce that may prove of the highest value and importance to this Country." 30 That the Japanese market could be opened was beyond doubt, as the merchants had "received the most flattering encouragement from conversation of Gentlemen of the greatest eminence and abilities (for Knowledge of Japan) that should our attempt meet with success, it may open a very extensive and valuable source of Commerce to this Country." 31

The Court of Directors of the East India Company succinctly indicated their

27 Report from London in The American Recorder (Charlestown, MA), 10 January 1786.

28 Carter, Sir Joseph Banks, 173. Thunberg to Banks, 16 May 1779, Br. Lib., Add.MS 8094, f.261; cited in David Mackay, In the Wake of Cook: Exploration, Science \& Empire, 1780-1801 (Wellington, NZ, Victoria UP, 1985), 61-2. Banks's interest in Japan was also manifested in his publication in 1791 of Engelbert Kaempfer's Japanese botanical drawings held in the British Museum, Icones selectae Plantarum quae in Japonia collegit et delineavit Engelbertus Kaempfer.

29 Uppsala Universitetsbiblioteket, Banks MSS, Ur: G 300c; cited in Glyndwr Williams, “"The Common Center of We Discoverers,' Sir Joseph Banks, Exploration and Empire in the Late 18th Century," in R.E.R. Banks et al., Sir Joseph Banks: A Global Perspective (London: Royal Botanical Gardens, Kew, 1994), 177-91.

30 British Library, India Office Records and Archives, Home Miscellaneous, 494 (5), 363; quoted in V. Harlow and F. Madden, British Colonial Developments, 1774-1834 (Oxford, 1953), 223.

31 British Library, India Office Records and Archives, Home Miscellaneous, 494 (5), 365; cited in Mackay, In the Wake of Cook, 63. 
understanding of the aims of the Etches scheme by referring to it in correspondence with the home secretary, Lord Sydney, as "an adventure to the North West Coast of America to procure furs to be disposed of at or near the Japanese islands." ${ }^{32}$ The instructions given to Portlock and Dixon, reflecting the advice from Thunberg, stated:

If a factory could possibly be settled on the island of Matmi [i.e. Matsumae, or Yezo, now Hokkaido], or any other convenient island contiguous to the north part of the island of Niphon, if this could be done with safety, or even if a friendly intercourse could be opened with the natives, it would be accomplishing a great object; but this must be entirely discretional. ${ }^{33}$

In early October 1785 the press carried an article which promoted the venture in the following terms:

It is with pleasure we hear, that the plan for carrying on a trade with the natives of King George's Sound, on the North West coast of America, is likely to be attended with the happiest effect to this country, as the scheme of these truly patriotic adventurers is not confined to that coast only, but extended to the island of Japan, the trade of which at present, the English are totally excluded from. Should this part of the plan succeed (and both the ships which are gone on this important expedition, have a great part of their cargoes adapted for Japanese traffic) it will be of the more consequence to this nation, than any commercial establishment now existing. ${ }^{34}$

\section{John Blankett's Proposals}

Another source of Banks's enthusiasm for opening trade with Japan was the views of John Blankett, a naval officer, who had been advocating this since 1774. The plan for Cook's voyage to the North Pacific (1776 to 1780) had been laid before the council of the Royal Society in February 1774 by Daines Barrington, but it had actually been drafted by Blankett, as he declared in a letter dated 24 February 1780 to Secretary of State Lord Shelburne which he wrote from Trincomalee, Ceylon (where he was serving with the East India squadron under the command of Admiral Sir Edward Hughes):

We have news from China, that the Discovery ships are arrived at Canton. Captains Cook and Clark have both died in the Expedition; Nothing of their Discoveries is spoke of. I must beg your Lordship if anything should arise of consequence from that Voyage to remember I was the proposer of it, Mr Daines Barrington having been the person who first laid my paper before the Royal Society in consequence of which they applied to my Lord Sandwich to undertake the Expedition. ${ }^{35}$

32 Devaynes and Smith to Sydney, 11 August 1785, British Library, India Office Records and Archives, Home Miscellaneous, 190/13:247; quoted in Harlow and Madden, British Colonial Developments, 27.

33 [John Etches], A Continuation of an Authentic Statement of All the Facts Relative to Nootka Sound (London: Fores, 1790), 23.

34 The Daily Universal Register and The Morning Post, 5 October, The Craftsman, 6 October 1785, and The Calcutta Gazette, 27 April 1786.

35 Shelburne correspondence, B,37; quoted in Howard T. Fry, "The Commercial Ambitions 
Blankett's plan for Cook's voyage had emphasized the possibilities for opening trade with North East China, Korea and the Japanese islands, and was set out in a memorandum on what he called "the Seas of Japan," which he had addressed to the first lord of the admiralty, Lord Sandwich on 11 December 1774. In it, he suggested:

That from any connection we might be able to form amongst the Islands in the vicinity of Japan, it would become the interest of that country to trade with us on equitable terms, as it would be in our power to cut off their communications with other Countries on which probably their principal commerce depends \& all these countries would take off vast quantities of our Manufactures \& open a new \& extensive branch of Commerce.... Japan even under its restricted Commerce is of more value to the Dutch, than any subjected Colony Great Britain can boast of... ${ }^{36}$

Blankett's sponsor at the Royal Society, Daines Barrington, urged exploration of "the coast of Corea, the Northern part of Japan, and the Lequieux Islands," work left unfinished by Cook, in the preface to his influential paper, "Polar Tracts," published in 1781. ${ }^{37}$ Cook's intention, before his death, to explore the coasts of China and Japan was subsequently confirmed by James Trevenen, who was a lieutenant on the Discovery under Cook on his last expedition, in a proposal he put to the Russian government for an expedition to the North Pacific, where he said: "Captain Cook, before his death, had intended employing the ships under him for this purpose. ${ }^{38}$ Blankett wrote to the prime minister, Lord Shelburne, in December 1782, and, in connection with plans for a "Chinese Embassy," he said:

The Kingdom of Corea and the Islands Liu-Kiu, are comprehended in this extension of Commerce which as it leads to open new [vents?] for our own Manufactures, I think will most likely meet your Lordship's meaning on Commercial Subjects. This made a part of the Plan submitted by me to Lord Sandwich in 1773 and by him [engrafted?] on Captain Cook's last Voyage but frustrated by his death. ${ }^{39}$

In a further letter to Shelburne in January 1783, Blankett said:

Since we lost the trade to Japan, we have never endeavoured to recover it. Probably this may be a proper time to make the trial, which cannot be attended with any great additional expence, and may be followed by the greatest advantages; it may be engrafted on the Plan

Behind Captain Cook's last Voyage," The New Zealand Journal of History VII, no. 2 (1973), 186-191.

36 National Maritime Museum (Greenwich), Sandwich Papers, Montagu F/5/38; quoted in Steven, Trade, Tactics and Territory, 25.

37 Daines Barrington, Miscellanies (London: Debrett, 1781).

38 James Trevenen to Count Vorontsov, February 1787, in Charles Vinicombe Penrose, A Memoir of James Trevenen, Christopher Lloyd and R.C. Anderson, eds., (London: Navy Records Society, 1959), 90-91.

39 Shelburne correspondence, Bowood House (Wilts), B,37; quoted in Howard T. Fry, "The Commercial Ambitions Behind Captain Cook's last Voyage," The New Zealand Journal of History VII, no. 2 (1973), 189. 
your Lordship has in contemplation of extending the Commerce of China and to those other

Places I have had the honour to mention to you. ${ }^{40}$

The plan for an embassy to China to which Blankett referred eventually took shape in 1787, when Charles Cathcart was appointed ambassador on 31 July. Among the records of the preparations for the embassy is a memorandum from Calcutta proposing that the ambassador also visit Japan:

...where I understand there is every reason to apprehend he will be well received from the Japanese Administration being perfectly relieved from the Apprehensions of the Christian Religion being again imposed or renewed by granting a free Commerce to the other European Nations as the Dutch who reside in Japan are no longer under the restraints imposed upon them about the beginning of this Century specified in Kempfer's relation, but at present enjoy the most liberal Encouragement and enlargement from their former fetters. This information I have from Mr. Titching the present Governor of Chinsurah who resided there many years. ${ }^{41}$

Cathcart sailed from Spithead on 21 December in the frigate Vestal. However, he died of illness before he could reach China, and the Vestal returned to England. The embassy was eventually undertaken by George, Lord Macartney, in $1793 .{ }^{42}$

\section{Joseph Banks's Role}

As president of the Royal Society, Banks was in a position to serve as a link between the ideas of Blankett and Thunberg on opening trade to Japan, and the ambitions of merchant adventurers represented by Etches to turn to advantage the discoveries made in the North Pacific during Cook's third voyage. The Royal Society had in 1774 taken up the proposals developed by Blankett and Barrington, which had led to their incorporation in the plans for Cook's third voyage. The discovery made during that voyage of the importance of the fur trade as a staple in North Asian commerce, in particular with Japan, and its publicisation by James King, led naturally to the idea of using the trade in furs obtained on the North West American coast as a lever for prying open the closed door to Japan. Banks was closely involved in the publication of King's account of Cook's third voyage. When the merchant adventurers represented by Etches approached him for advice on how to exploit the resources of the North West American coast, Banks could draw to their attention the possibilities of trade with Japan, perhaps by using the indirect approach to the country of establishing a trading factory in the Ryukyus, or the islands between Japan and Korea such as Tsushima or Cheju, or the Kurils or Yezo to the north of Japan. These outlying islands were not so closely under the control of the government at Edo, and through them some trade was already taking place between Japan and the outside world. As an adviser to the government, the president of the Royal Society could

40 Shelburne correspondence, quoted in Fry, New Zealand Journal of History, 191.

41 British Library, India Office Records and Archives, Factory Records, China, G/12/20; cited in V.T. Harlow, The Founding of the Second British Empire, Vol. 2 (London: Longmans, 1964), 583. 
serve as a natural focus for developing the scheme for trading with Japan based on newly established British settlements on opposite sides of the Pacific at Botany Bay and Nootka Sound, and on the already existing factories at Canton. ${ }^{43}$

The extent and value of the North Pacific fur trade had been revealed to English readers by the publication in London in 1780 of An Account of the Russian Discoveries between Asia and America; to which are added, The Conquest of Siberia and the History of the Transactions and Commerce between Russia and China by William Coxe, a senior fellow of King's College, Cambridge. Coxe described the exchange between the Russians and Chinese conducted at the annual fairs at Kyakhta, on the Siberian-Mongolian border:

The furs of Kamchatka and of the Eastern Isles were then conveyed from that peninsula by water to Okotsk; from there to Yakutsk by land on horseback or by reindeer. The roads were so very bad that the journey lasted at least six weeks. At Yakutsk, the goods were embarked upon the Lena, towed up the stream, then downstream, and across Lake Baikal to the mouth of the Selenga River, and up that river to the neighbourhood of Kiakta. The Chinese transported their goods to Kiakta chiefly upon camels. ${ }^{44}$

James King's description in the official account of Cook's third voyage, $A$ Voyage to the Pacific Ocean (published in May 1784), of the possibilities of trade with Japan was well calculated the attract the attention of ambitious merchant adventurers:

The Russian merchants have a still larger profit upon the furs at Kiachta, on the frontiers of China, which is the great market for them. The best sea otter skins sell generally in Kamchatka, for about thirty rubles apiece. The Chinese market at Kiachta purchases them at more than double that price, and sells them again at Pekin at a great advance, where a further profitable trade is made with some of them to Japan. If, therefore, a skin is worth thirty rubles in Kamchatka, to be transported first to Okotsk, thence to be conveyed to Kiachta, a distance of one thousand three hundred and fifty-four miles, thence to Pekin, seven hundred and sixty-miles more, and after this to be transported to Japan, what a prodigiously advantageous trade might be carried on between this place and Japan, which is but about a fortnight's, at most, three weeks sail from it? ${ }^{45}$

\section{George Dixon and William Bolts}

A mercantile response to the enticing prospects held out by King was not slow to eventuate. British merchants in Canton and in Indian ports were in a position to take prompt action in response to the revelation of fortunes to be made from the trade in sea otter furs. In April 1785, the 60-ton brig Sea Otter sailed from Macao for the North West coast under the command of James Hanna. The vessel was chartered by John Henry Cox, a Canton merchant, on behalf of backers in India and Canton. One of these was John Reid,

43 Glyndwr Williams, Sir Joseph Banks, 177-91; and Gascoigne, Science in the Service of Empire, 186-7.

44 William Coxe, An Account of the Russian Discoveries between Asia and America; to which are added, The Conquest of Siberia and the History of the Transactions and Commerce between Russia and China (London, 1780), 333-7, 341-2, 350. 
who had been set up as Austrian consul and agent at Canton of the Imperial Asiatic Company in October 1779 by the company's head, William Bolts. ${ }^{46} \mathrm{He}$ was there when James Cook's ships, the Resolution and Discovery, called at nearby Macao in NovemberDecember 1779. Cook had been killed at Hawaii, and the ships were on their return to England under the command of John Gore. James King, commander of the Resolution, made a visit to Canton and while he was there the crew of the ships sold for amazing prices the sea otter pelts they had obtained for trinkets in barter with the natives of the North West coast of America. ${ }^{47}$ Reid apparently got word of this to Bolts, then at Mauritius or Cape Town. Bolts afterwards wrote that he had the ambition of wishing to be the first to profit from this new branch of trade ${ }^{48} \mathrm{He}$ spent the next five years trying to achieve this goal. He bought a ship, the Cobenzell, in England in November 1781, which he hoped to send round Cape Horn, take on furs at Nootka which would be sold in China and Japan, and return by the Cape of Good Hope. Four sailors who had been to the North West coast on Cook's last voyage were engaged by Bolts: one of them, George Dixon, was to be the second in command under a Hungarian captain, John Joseph Bauer. Bolts laid a proposal in May 1782 before the Emperor Joseph II, who for a time was attracted to the idea of an Austrian scientific voyage round the world similar to those performed for Great Britain by Captain Cook, which would be self-financing according to Bolts's proposal. Eventually, the inadvisability of attempting to combine scientific with commercial aims in a single voyage became obvious, and in November 1782 Bolts obtained the emperor's permission to put his proposal to the court of Catherine II of Russia, and when that met with no response, before the court of Joseph's brother-in-law, Louis XVI of France. The French response was more positive but the resulting venture commanded by Lapérouse in August 1785 proceeded purely as a voyage of discovery instead of a commercial voyage with some scientific aims as proposed by Bolts. ${ }^{49}$

In January 1786, the Imperial East India Company that Bolts had founded ten years before collapsed. His financial partners in the company, a consortium led by the Antwerp banking house of Charles Proli, had forced him to relinquish control after his return from India in 1781 and their incompetence had subsequently driven it to bankruptcy. ${ }^{50}$ Although he possessed no capital himself, Bolts was able to trade on his

46 Franz von Pollack-Parnau, "Eine österreich-ostindische Handelskompanie, 1775-1785: Beitrag zur österreichische Wirtschaftsgeschichte unter Maria Theresia und Joseph II," Vierteljahrsschrift für Sozial- und Wirtschaftsgesichte, Beiheft 12 (Stuttgart, 1927), 42, 78. Canton Consultations, 27 September 1783, British Library, India Office Records and Archives, G 12/77, ff. 81, 98. W. Kaye Lamb and Tomás Bartroli, "James Hanna and John Henry Cox: the First Maritime Fur Trader and His Sponsor," BC Studies LXXXIV (1989-90), 3-36.

47 Catherine Gaziello, L'expédition de Lapérouse, 1785-1788 (Paris, 1984), 49-50.

48 Guillaume Bolts, Recueil de pièces authentiques, relatives aux affaires de la ci-devant Société impériale asiatique de Trieste, gérées à Anvers (Antwerp, 1787), 104-5.

49 Robert J. King, "William Bolts and the Austrian Origins of the Lapérouse Expedition," Terrae Incognitae XL (2008), 1-28.

50 Barry M. Gough and Robert J. King, "William Bolts: An Eighteenth Century Merchant Adventurer," Archives: the Journal of the British Records Association XXXI, no. 112 (April 
reputation as an expert in the Eastern trade to launch a new share company in 1783, the Triestine Society, which in September 1783 sent the Cobenzell on a commercial voyage to India by way of the Cape of Good Hope..$^{51}$ Bolts still wished to carry out his North West coast venture and outfitted a ship in Marseilles, the Ferdinand, in which he sought to carry out the venture under the flag of King Ferdinand of Naples, but again the attempt came to nought. ${ }^{52}$ George Dixon went back to England, where he sought to interest Sir Joseph Banks and English merchants in the North West coast fur trade. ${ }^{53}$ This resulted in the formation of the Etches consortium, of which Dixon became a member with appointment as captain of the Queen Charlotte. ${ }^{54}$ The similarity is notable between the plan of the consortium and that elaborated by Bolts, which was apparently communicated to them by Dixon. ${ }^{55}$ The proposal they submitted to the East India Company in April 1785 said:

Some time ago Mr. Bolts assisted by the Imperial Asiatic Company proposed to make this attempt; they built a ship at Marseilles [the Ferdinand] — and procured some of the people who were round [the world] with Captain Cook — they made offers to a Mr. Dixon, a man of great abilities, and complete from his experience for such an undertaking

- not meeting with encouragement here, he accepted the offer-but the affairs of the Company stopped it. ${ }^{56}$

\section{James Hanna's Voyage}

It is likely that Bolts had had an interest in Hanna's voyage through his connection

2005), 8-28.

51 Wiener Zeitung, 15 and 18 January 1783. Sir Richard Temple, "Austria's Commercial Venture in India in the Eighteenth Century," Indian Antiquary XLVII (April 1918), 85-92.

52 This episode is described in Robert J King, "Heinrich Zimmermann and the Proposed Voyage of the Imperial and Royal Ship Cobenzell to the North West Coast in 1782-1783," presented at the Canadian Nautical Research Society Conference, "Pacific Navigation," Victoria, British Columbia, 12-15 August 2009.

53 Dixon to Banks, 27 August 1784 and Banks to Dixon, 29 August 1784, British Museum (Natural History), Dawson Turner Transcripts of Banks Correspondence, IV, 47-49; cited in Mackay, In the Wake of Cook, 60-61.

54 George Dixon (Johann Reinhold Forster übersetzt), Der Kapitaine Portlock's und Dixon's Reise um die Welt (Berlin, Voss, 1790), Vorrede des Uebersetzers, 11; Harlow, The Founding of the Second British Empire, 2: 420.

55 Instructions to Portlock and Dixon, September 1785; quoted in [John Etches], A Continuation of an Authentic Statement of All the Facts Relative to Nootka Sound, 18-29. The Etches consortium scheme is discussed in Robert J. King, "A regular and reciprocal System of Commerce': Botany Bay, Nootka Sound, and the isles of Japan," The Great Circle XIX, no. 1 (1997), 1-29.

56 "Additional Proposals relative to the establishing a Trade between the North West Coast of America and the Coast of Asia, the Japanese Islands \&ca, laid before the Court of Directors, 29 April 1785," British Library, India Office Records and Archives, Home Miscellaneous, vol. 494, p. 366; also at British Columbia Provincial Archives, Victoria, A/A/10/G79 H494; quoted in V. Harlow and F. Madden, British Colonial Developments, 24. 
with Reid, and Nathaniel Portlock said that it owed its inspiration to Bolts. ${ }^{57}$ Hanna made a most profitable voyage, and his success on the Canton market upon his return more than fulfilled the promise held out by the experience of the crews of the Resolution and Discovery. Word of this success was sent back to England and reported in the London press on 21 September 1786:

The Sea Otter, Capt. Hannah, is arrived from King George's Sound, on the West coast of America, after one of the most prosperous voyages, perhaps, ever made in so short a time... the furs she collected were sold at Canton for upwards of $30,0001 \ldots$. The beauty of these furs is beyond description, and held by the Chinese in the highest estimation: it is astonishing with what rapidity they purchased them. - Captain Hannah acquainted me that there were several sent home to England as presents; your friend Sir Joseph Banks hath two of them sent by this ship, where no doubt you will see them. - It is astonishing that this business hath not been taken up long before this directly from England, as there is a full description of it in the publication you sent me of Capt. Cook's last voyage: it is fully expected that when the astonishing value of this trade is well known in England, that the Company will send out some of their China ships to trade for furs on that coast, and to try to open a trade from Japan for the disposal of them. Should they be able to accomplish this trade it would be a great acquisition, as it would procure them vast quantities of silver and gold, and the furs would sell for 300 per cent. more than they do at China. The trade is carried on by the Chinese at an amazing advantage. ${ }^{58}$

Cox and his associates chartered Hanna for another voyage in May 1786. Hanna died during preparations for a third voyage, but in the meantime, Cox had also chartered the Lark, which left Macao under the command of William Peters in July 1786. Peters was instructed to make his passage between Japan and Korea, and to examine the islands to the north of Japan. ${ }^{59}$ After calling at Matsumae (Yezo) and Petropavlovsk, he was lost with his vessel on Mednoi (Copper) Island, one of the Commander Islands. ${ }^{60}$ The Calcutta Gazette of 4 April 1793 reported:

The Phoenix, Captain Moore, just returned from the N.W. Coast of America, brings the first substantiated accounts which we have heard of the loss of the Lark, Captain Peters, which vessel was fitted out from this port some years ago. The Lark was lost on Beering's Island off Kamscatca [in fact, on the neighbouring Mednyy, or Copper Island], and several of the crew got on shore; but owing to the hardships they underwent from the inclemency of the climate, and want of necessaries, only four survived, who were relieved by a Russian vessel, which carried them to Siberia, where they have met with the most humane and attentive treatment from the Russians - they are two Portugeze and two lascars, and are still residing at Irkush in Siberia.

\section{John Meares's Venture}

57 Nathaniel Portlock, A Voyage Round the World (London: Stockdale, 1789), 2-3.

58 The London Chronicle; The Whitehall Evening Post; St. James's Chronicle and The Morning Post, 22 September 1786.

59 European Magazine (November 1788). Lamb and Bartroli, "James Hanna and John Henry Cox"; and W. Kaye Lamb, "Postscript," BC Studies LXXXVIII (1990-91), 93-4.

60 J. J. B. de Lesseps, Travels in Kamchatka, vol. 1 (London, 1790), 10-11. 
Opening a trade to Japan in sea otter furs was also the aim of the venture led by John Meares on behalf of the Bengal Fur Society. In February 1786, Meares sailed from Calcutta in command of the Nootka, together with a companion ship, the Sea Otter, under William Tipping. They reached Nootka Sound in September and August, respectively. Tipping had come by way of Japan, where he had made contact with the inhabitants. He had been ordered by Meares "to endeavour to open an amicable Intercourse with the Inhabitants of Corea or Japan, or the Islands to the North or South." ${ }^{.61}$ Later, Meares explained: "I had given these Orders in consequence of some imperfect Knowledge we had obtained of a communication between the Chinese, Japanese and Coreans. Those Empires being at Hostility with each other, the only Communication carried on between them was through the Islands lying in those Seas." ${ }^{62}$ The venture was reported in The Whitehall Evening Post of 22 September 1786:

Recent letters from Bengal... advise, that a subscription was entered into at Calcutta to the amount of eighty thousand pounds, for the purpose of carrying on a fur trade from Kamschatka and the opposite coast of America to China and the East-Indies, pursuant to the plan of the late Capt. Cooke and his associate circumnavigators; in consequence of which two ships of 250 tons each, had sailed on that trade from Calcutta on the first day of February last, under the command and direction of Capt. Meares, a native of Dublin. ${ }^{63}$

The General Evening Post of 1 February 1787 carried a report from St Petersburg dated 19 December 1786, which presumably referred to the Lark, under Peters, and the Sea Otter, under Tipping:

Accounts are received from Capt. Ismayloff, Governor of Kamtschatka, that two armed ships, under English colours, from the coast of America, with a cargo of furs, were put into the island of Metmi [Matsumae, i.e. Yezo]; that on their arrival they were not allowed to land or even traffic for fresh provisions, but after making the Prince some valuable presents of European articles, they had entered into a league of friendship with him for the carrying on a traffic with the Japanese for the disposal of their cargoes, which chiefly consisted of furs; that before the sloop which brought the intelligence sailed from Metmi, they had made several voyages to the Coast of Japan, and met with great success; that they were preparing to leave some of their people on the island, to whom the Prince had promised protection; and had actually betrothed one of his daughters to the supercargo who was to be left on the island as commander of the party, for the carrying on a correspondence with the Japanese and Kurile islands. ${ }^{64}$

61 Meares's evidence to the Committee of the Privy Council for Trade, 8 February 1791, National Archives (Kew), Privy Council Register, PC 2/135, 439-444; quoted in Harlow, The Founding of the Second British Empire, 2: 433.

62 Meares's evidence to the Committee of the Privy Council for Trade, 8 February 1791, National Archives (Kew), Privy Council Register, PC 2/135, 439-444; quoted in Harlow, The Founding of the Second British Empire, 2: 433.

63 Meares's father was Charles Meares, "formerly an attorney of great eminence, and for several years pursuivant of his Majesty's Court of Exchequer in [Dublin]" (The Gentleman's Magazine LX, pt. II, no.2 (August 1790), death notices for 31 July, 767). 
The independent merchants, John Henry Cox and his partner, Daniel Beale, based at that time in Canton/Macao, had an interest in Meares's voyage. ${ }^{65}$ Upon returning to Macao, Meares formally enlisted their financial support and, as the "Merchant Proprietors," they issued him with instructions dated 24 December 1787. On 20 January 1788, Meares sailed again for the North West coast in the Nootka (now sailing under Portuguese colours to avoid East India Company restrictions and renamed the Felice Aventureira). As Tipping had been lost with the Sea Otter, his new consort was the Iphigenia Nubiana under William Douglas. Cox was compelled by the East India Company to leave Canton in early 1788 and returned to England. He was probably the author of an article, "New Fur Trade," published in The World, 6 and 13 October 1788, and The European Magazine for November 1788. The article referred to Meares's departure for the North West coast in January 1788 in the following terms:

The exclusive privilege granted to a Society in England, having prevented all expeditions to the N.W. coast from any of the British settlements in the East, two coppered vessels, the Nostra Signora de Felix Aventura e Discoverto, of 200 tons, and the Nostra Signora de Bom Successo, of 100 tons, were fitted out by an enterprising Portuguese Merchant of Macao. These vessels sailed from the Typa [Macao] in the month of January 1788, commanded by English officers who had served in the former expeditions to that coast.

Meares explained his hopes regarding trade with Japan in testimony before the Committee of the Privy Council for Trade, which he gave on 27 May 1790. In answer to a question on what prospect he believed he had of opening a trade in furs and other articles of commerce with Japan, Meares replied:

The prospect arises from the Information we received in China of the value of these Furs in Japan; and we received the like Information from the Governor of Chinsura, who was chief of the Dutch Factory in Japan for Ten years. We meant to have gone in our own ships with them to Japan.

When asked if he had any reason to suppose that he would be permitted by the government at Japan to trade in their territories, Meares answered:

We had, for we conceive the Empire of Japan to consist of a number of Islands. The great Island Niphon is under the immediate inspection of the existing Government, but the other surrounding Islands are under the command of great Lords who are nearly independant of the principal Government. We received Information of the nature of this Commerce principally from Manilla, from whence a considerable commerce is now carried on to these Japanese Islands, in China Junks, by the people of the Philippine Islands, subjects of the Spanish Government, who go in these Junks dressed in the Habits of the Philippine Islands. We know of no European Ships that have of late Years gone to these Islands, except Dutch,

65 Meares's evidence to the Committee of the Privy Council for Trade, 27 May 1790, National Archives (Kew), BT, 5/6, ff. 225-31; also at Br. Lib., Add MS 38,392, ff. 114-21. In 1791, Cox returned to the North West coast in the Mercury (or Gustavus III); see George Mortimer, Observations and Remarks made during a Voyage... in the Brig Mercury (London, 1791, repr, New York: N. Israel, 1975). See also Rolf E. Du Rietz, "A secret Anglo-Swedish naval expedition to the Pacific in 1789," Banksia (Uppsala) no. 5 (2002). 
but we had so much confidence in the probability of opening a Trade with these Islands that we were determined to fit out a Ship laden with these American Furs and with European Manufactures and to have sent her to the Japanese Islands. We have understood that English Broad Cloth, sold by English Merchants in China, is frequently carried from thence to the Japanese Islands and there re-sold at a very advanced Price... We give no credit to, but ascribe to interested motives the Reports that are spread of the personal aversion of the Japanese to Trade with the Europeans... We understood that the people of these Islands were very wealthy and knew we possessed those Articles of which they were in want, and therefore we expected to carry on a very lucrative Commerce with them. ${ }^{66}$

The governor of the Dutch factory at Chinsura in Bengal, near Calcutta, to whom Meares referred, was Isaac Titsingh. Titsingh was Opperhoofd or Captain at Dejima (Nagasaki) twice between 1779 and 1783, and became an ardent Japanophile as a result of the personal friendships he was able to develop with eminent Japanese in the more relaxed atmosphere prevailing during his period there. At that time, the policy of the Shogun's chief minister, Tanuma Okitsugu, was favourable to increased openness toward foreigners (as Thunberg had experienced). Almost unique among the Dutch at Dejima, Titsingh gained some facility with the Japanese language. One of his Japanese friends was Shimazu Shigehide, the Daimyo of Satsuma and overlord of the Ryukyus (Liu Kiu islands), a vassal kingdom through which Satsuma conducted a highly profitable clandestine "tribute" trade with China, circumventing the Tokugawa Shogunate's ban on foreign commerce. Titsingh left Japan in 1783, like Thunberg, with the strong impression that the country might soon abandon its policy of seclusion. When he subsequently became captain of the Dutch factory at Chinsura, he had frequent contact with English friends, to whom he communicated his views on Japan, such as the author of the above quoted memorandum urging that the proposed embassy to China also visit Japan. ${ }^{67}$ The tenor of these views is revealed in Illustrations of Japan, compiled from his papers and published after his death:

When they turn their eyes to neighbouring nations, they observe that the admission of foreigners is not injurious to the government; and that a similar admission of strangers into their own country would furnish them with the means of studying a variety of arts and sciences of which they have but vague notions... Though many Japanese of the highest distinction and intimately acquainted with matters of government, still consider Japan as the first empire in the world, and care but little for what passes out of it, yet such persons are denominated by the most enlightened as Inooetzi-no Kajerou [I no uchi no Kaeru], or frogs in a well, a metaphorical expression, which signifies that when they look up, they can see no more of the sky than what the small circumference of the wall allows them to perceive. The eyes of the better informed had been long fixed on Tonomayamassiro-no kami, son of the ordinary counsellor of state Tonomo-no-kami [Tanuma Okitsugu], uncle to the Djogoun, a young man of uncommon merit, and of an enterprising mind. They flattered themselves that when he should succeed his father, he would as they expressed it, widen the road. After his appointment to be extraordinary counsellor of state, he and his father incurred the hatred of the grandees of the court by

66 Meares's evidence to the Committee of the Privy Council for Trade, 27 May 1790, National Archives (Kew), BT, 5/6, ff. 225-31; also at British Library, Add MS 38,392, ff. 114-21.

67 British Library, India Office Records and Archives, Factory Records, China, G/12/20; cited in Harlow, The Founding of the Second British Empire, 2: 583. 
introducing various innovations, censured by the latter as detrimental to the welfare of the empire. He was assassinated on the $13^{\text {th }}$ of May, 1784, by Sanno-Sinsayemon, as related in my Annals of Japan. This crime put an end to all hopes of seeing Japan opened to foreigners, and its inhabitants visiting other countries. Nothing more, however, would be required for the success of such a project, than one man of truly enlightened mind and of imposing character. ${ }^{68}$

\section{A Settlement at Nootka Sound}

In London, Richard Etches continued to promote the King George's Sound venture. In a letter to Banks dated 17 July 1788, he reaffirmed "our Intention is to adopt a Permanent system of Commerce direct from this Country to the N.W. Coast and from thence to the Asiatic Coast, and Islands. ${ }^{\circ 9}$ He made it clear that he saw the importance of the venture as going well beyond the private interests of merchants, and confessed his longcherished aim of establishing a settlement on the North West coast, "not only as an Individual, but a National attempt." He sought Banks's continuing support in obtaining government protection. "There is one Idea," he went on, "which perhaps may not be immediately thought of, which with all possible defference I will beg leave to suggest to You, Government having adopted the measure of Colonizing with Convicts, I shou'd presume the same wou'd hold good with forming an establishment on the N.W. Continent of America or Islands, equally with New Holland."

Banks responded to Etches that the expense of establishing a convict settlement on the North West coast would forbid its consideration by government. On 20 July, Etches wrote again to Banks, outlining his plans, reiterating the national importance of his proposal, and insisting that government protection was essential to its success. $\mathrm{He}$ concluded: "A foundation thus laid, and as it is no longer to be doubted but there are plenty of furs to be met with, a market for their disposal wou'd be the whole to seek for, the opposite shores afford ample field, and I am perfectly satisfied that the Japan Islands may be attempted with success." Referring to Tipping's voyage in the Sea Otter, he continued, "I understand that a Country Ship sail'd thro' the Archipelago, and even landed on the Island of Nyphon, and that the Natives behav'd very friendly, tho' our first Ships have not made the attempt, owing to the Season being too far advanc'd - I am determin'd the rest shall. ${ }^{, 70}$ He wrote again to Banks on 8 August 1788, saying that he would be "very much obliged to him if he will be so kind as to favor him with any particulars he can (or to acquaint him where he can learn) respecting the Commotions in Japan - I mean relative to the Commercial part - what part he deems the most probable to open an intercourse with them in Furs." He went on: "I am writing to my Brother (by the pacquet) at Canton who purposes shou'd he be too late in the Season on his return from the N West to run down the

68 Isaac Titsingh, Illustrations of Japan, Frederic Shoberl, trans. (London: Ackermann, 1822), 182-3.

69 California State Library, Sutro Branch, Banks Papers, PN 1/6; quoted in F.W. Howay, "Four Letters from Richard Cadman Etches to Sir Joseph Banks, 1788-92," British Columbia Historical Quarterly VI, no. 2, (April 1942), 125-39.

70 California State Library, Sutro Branch, San Francisco, Banks Papers, PN 1/7. 
Coast of Japan to purchase a Vessell and take part of his Furs to that Coast in the highth of summer."71

\section{The Spanish Arrest James Colnett at Nootka}

The "first Ships" to which Etches referred were the King George and the Queen Charlotte. Subsequently, the King George's Sound Company had sent the Prince of Wales and the Princess Royal, under the command respectively of Cook veteran James Colnett (like Meares, a Royal Navy lieutenant) and Charles Duncan. With John Etches (Richard's brother) in the Prince of Wales as supercargo, they left London on 16 October 1787. They spent the summers of 1787 and 1788 on the North West coast, and by 13 November 1788 were at Macao. There, on 23 January 1789, they entered into a partnership with Meares and his associates, Cox and Beale, forming the "Associated Merchants of London and India Trading to the Northwest Coast of America." The new consortium purchased a 120 ton snow, named her the Argonaut, and placed her under the command of Colnett. ${ }^{72}$ The Argonaut left Macao on 25 April 1789 with instructions from Meares to set up a permanent factory at Nootka Sound, "a solid establishment and not one that is to be abandoned at pleasure," and carrying thirty Chinese carpenters and artisans to build and populate this settlement. ${ }^{73}$ Upon her arrival at Nootka, she and her two consorts, the Princess Royal and the Northwest America, were seized and Colnett arrested in the name of the King of Spain and the Indies by Estéban José Martínez, who had been sent in command of the Princesa (26 guns) and the San Carlos (16 guns) to enforce Spain's territorial claims to the area.

Upon receiving an account of the Spanish seizure of the Argonaut and its consorts, the Princess Royal and the Northwest America, from his brother, John, Richard Etches wrote to Banks on 6 May 1790, saying:

I am favour'd by my brother with an Account of the arrival of Captain Meares from Canton, who brings official Accounts of the seizure of all our Ships, Craft and the whole of the Establishment on the N W Coast by a Spanish Admiral, what pretensions they can have to such a Act, I am as yet a stranger - except it is that monstrous, and absur'd, claim which they set up in the last Century "An exclusive right to the Navigation, Territories and Commerce of that quarter of the Globe" - When the Spanish Admiral arriv'd — we had founded the principles of a permanent, and regular System of Commerce, on a wide and extensive Scale, there was every prospect of our accomplishing of the long wish'd for object, the Opening an intercourse with the Japanese Islands for the Sale of our Furs, and American produce - the certainty of Establishing a very Valuable fishery was evident and equally so of it proving a Store of Commercial Wealth to the English Nation - I cannot doubt but that England will claim her just rights, and the limits and boundaries of the two nations will be properly adjusted — and that the Valuable discoveries of Adml. Drake \&ca will not be pass'd over — ${ }^{74}$

71 Kew Herbarium Library, Banks Correspondence, Vol. 1, no. 314.

72 Robert Galois, ed., A voyage to the North West Side of America: the Journals of James Colnett, 1786-89 (Vancouver: UBC Press, 2004).

73 Meares's instructions to Colnett, 17 April 1789; Meares, Voyages, appendix I; quoted in Steven, 51.

74 Etches to Banks, 6 May 1790, Kew Herbarium Library, Banks Correspondence, Vol. 2, no. 
Reporting on the Spanish seizure of the ships at Nootka, an article in The Whitehall Evening Post of 8 May 1790 described the objectives of the Etches-Meares venture:

A new source of commerce to the kingdom of Japan had been meditated in consequence of Mr. Mears's residence in China, and the traffic of his ships. For this purpose he was preparing to proceed to Nagasaqui, the principal port of Japan, with a cargo suited for the trade to that country; which, had it been suffered to be carried into effect, would have been a most important object, and have afforded a considerable consumption for our own manufactures. The Japanese Empire is an immense tract of country; and, before Mr. Mears left China, certain accounts had been received there of the importation of English Woollens into Japan by the Chinese, as well as of the Sea Otters skins that had been brought to Canton by the English vessels employed in the trade to Nootka. It was therefore intended to forestall the Chinese in this traffic, and to carry it on in English bottoms, which has been prevented by this seizure of the Spaniards.

\section{Nootka to be settled from New South Wales}

The Spanish seizure of Colnett's ships provoked the British Government to extend that protection to the North West fur trade for which Etches had long pleaded. Home Office under-secretary Evan Nepean drafted a letter to the Admiralty in early February 1790, outlining the government's response to the events at Nootka Sound, saying "His Majesty has judged it highly expedient that measures should instantly be taken for affording protection to such of His... Subjects as may have already proceeded to that part of the American Continent." 75 In the plans drawn up under Nepean's direction, the New South Wales settlement was assigned the part foreshadowed for it of assisting the North Pacific fur trade. ${ }^{76}$ Instructions were drawn up for Governor Arthur Phillip at Port Jackson to supply a detachment of marines and convict workers - thirty persons altogether, with stores - to an expedition whose object would be to form a settlement on the North West coast, which would "lay the foundation of an establishment for the assistance of His Majesty's subjects in the prosecution of the Fur trade from the North West Coast of America." $" 77$ The proposed expedition was to consist of three ships, two of which, the Gorgon (44 guns) and Discovery (10 guns), were to go first to Port Jackson. The Gorgon was already preparing to go there with new troops and stores for the colony, and the Discovery was readying for a voyage of exploration to the South Atlantic. If, upon arrival

11; quoted in Mackay, In the Wake of Cook, 93.

75 "Sketch of a Letter to the Admiralty," undated but early February 1790, HO 28/7, ff. 48-56; cited in Mackay, In the Wake of Cook, 89; also cited in Alan Frost, "Nootka Sound and the Beginnings of Britain's Imperialism of Free Trade," Robin Fisher and Hugh Johnson, eds., Maps to Metaphors: The Pacific World of George Vancouver (Vancouver: University of British Columbia Press, 1993), 112-16.

76 "Heads of Instructions," February 1790, HO 42/16, f. 10; cited in Mackay, In the Wake of Cook, 89.

77 Nepean to Phillip, March 1790 (draft), HO 201/1, ff. 19-24; photoduplicated in Jonathan King, "In the Beginning..." The Story of the Creation of Australia, From the Original Writings (Melbourne: Macmillan, 1985), 235-240. 
of the ships at Port Jackson, the 21-gun frigate stationed there, the Sirius, was available, the 10-gun Discovery would take her place and Sirius would accompany Gorgon to the North West Coast (unknown at this time in London, the Sirius had been wrecked on Norfolk Island in March 1789). From Port Jackson, the two ships were to proceed to Hawaii, where they would rendezvous with a frigate sent from India, from whence all three would proceed under the command of the frigate captain to the American coast. There, a settlement was to be made at Queen Charlotte Sound or Fitzhugh Sound, and Discovery was to be used for making a survey of the coast. ${ }^{78}$ The Gazetteer of 8 May 1790 carried an article which referred to the new Act for enabling his Majesty to authorise his governor or lieutenant governor of such places beyond the seas, to which felons or other offenders may be transported, to remit the sentences of such offenders:

By the bill passed into law this Session, the Settlement of Botany Bay may be made useful in case of a rupture. The Governor is empowered to remit the remaining term of the sentence of such persons as shall behave well. Under this Act he may therefore embark a number of them on board King's ships, and make them act as soldiers on any adventure. ${ }^{79}$

The Gorgon and Discovery were on the point of departure from England at the end of April 1790 when John Meares arrived there claiming to have already established a settlement at Nootka Sound. Accepting Meares's claim, the British Government now decided to use the incident to force Spain to retract her claims to exclusivity on the western coasts of both North and South America. The proposed expedition was cancelled and the Pitt Government decided to send an ultimatum to Madrid, backed by the mobilisation of the entire fleet. Events moved toward an international crisis, threatening an outbreak of a general European war. Plans were made for naval expeditions against Spain's possessions in the Americas and the Philippines. ${ }^{80}$ The crisis lasted until October 1790, when a convention settling the issues of navigation and colonization in the Pacific was signed between Great Britain and Spain.

The Spanish view of the objects of British policy in the Pacific was reported by Alleyne Fitzherbert, ambassador to Madrid, who said in a letter dated 16 June 1790 to Foreign Secretary Leeds that at a private meeting the prime minister, Count Floridablanca:

gave me to understand that he considered our sending Ships to purchase Skins at Nootka as a shallow artifice calculated to cover a real design of making ourselves masters of the Trade of Mexico, that our Southern Whale Fishery covered a like design against Peru \& Chili, and

78 Grenville to Cornwallis, 31 March 1790, National Archives (Kew), HO 28/61, ff.273-290v; cited in W. Kaye Lamb, ed., The Voyage of George Vancouver, 1791-1795, vol. 1 (London: Hakluyt Society, 1984), 24; also cited in Mackay, In the Wake of Cook, 90; and in Frost, Maps to Metaphors, 115.

7930 Geo. III 47, in Historical Records of New South Wales (Sydney, 1893), vol. 1, pt. 2, 67-68.

80 These plans are discussed in Robert J. King, "An Australian Perspective on the English Invasions of the Rio de la Plata in 1806 and 1807," International Journal of Naval History 8, no. 1 (April 2009), at: www.ijnhonline.org/volume8_number1_Apr09/pdf/Article - King.doc 
as to our colony at Botany-Bay that it must necessarily have been founded with a view to seconding these designs \& of adding to our other conquests that of the Philippines. ${ }^{81}$

Floridablanca could have drawn support for his views from any number of reports published in the English press, such as the selection drawn from The General Advertiser and other London newspapers of 12, 13 and 14 October 1786, based on James Matra's proposal for colonization of New South Wales, sent to him by the Spanish ambassador, Campo de Alange. ${ }^{82}$

\section{George Vancouver's attempt to regain Nootka}

The last attempt to use the Botany Bay settlement as a base to support British exploitation of the resources of the North West American coast took place in 1792. In accordance with the terms of the Anglo-Spanish Convention of 18 October 1790 settling the Nootka Sound dispute, George Vancouver was sent in command of the Discovery and Chatham, supported by the chartered storeship Daedalus, to accept the restoration of the buildings and land at Nootka of which Meares claimed to have been dispossessed by the Spaniards, and with the intention of founding a British settlement there, "It being his Majesty's intention," as Nepean said, "that an Establishment should be formed at one of those ports or places, of which His Subjects have been dispossessed or in such other situation as shall appear to be more advantageous." 83 The master of the Discovery, Joseph Whidbey, indicated his understanding that a settlement was to be made on the North West Coast in a letter he wrote from Monterey on 2 January 1793: "I am informed Botany Bay as [has] not answered its expectations - the Convicts who have served their time of punishment and instead of returning to England to become a fresh prey on the Public, to be sent to this Country and settled at the Head of Fuca Straights." 84

The owner of the Daedalus, Alexander Davison, anticipated the growth of a thriving trade following the re-establishment of a British presence at Nootka: he wrote to the East India Company's supercargo at Canton that he had instructed the ship's master, Thomas New, when he reached Nootka "to purchase as many Skins as he possibly can"

81 Fitzherbert to Leeds, 16 June 1790, British Library Add. MS 28066, ff. 27-28; quoted in Harlow, The Founding of the Second British Empire, 2: 634.

82 Campo to Florida Blanca, 13 Octubre 1786, Archivo Historico Nacional, Madrid, Estado, legajo 4250/1.

83 Nepean to the Lords Commissioners of the Admiralty, 28 December 1790, National Archives (Kew), ADM 3/107: 447; cited in Mackay, In the Wake of Cook, 96, 119; also at HO 28/7, ff. 392-9; quoted in Alan Frost, "Science for Political Purposes: the European Nations' Explorations of the Pacific Ocean, 1764-1806," in Juan Carlos Luna et al., Spanish Pacific: from Magellan to Malaspina (Madrid: Ministerio de Asuntos Exteriores y Lunwerg Editores, 1988), 89-105; also in Roy MacLeod and Philip F. Rehbock, eds., Nature in its Greatest Extent: Western Science in the Pacific, Acts of the 17th International Congress on the History of Sciences, University of California, Berkeley, 1985, Vol.VII (Honolulu: University of Hawaii Press, 1988), 27-44.

84 Joseph Whidbey, letter of 2 January 1793 at Monterey, quoted in Lamb, The Voyage of George Vancouver, 1637. 
and after arriving at Port Jackson to consign them by another ship or take them himself in the Daedalus to Canton for sale by the supercargo. "I expect this business may become an object of much consideration and benefit, and as it may be successful or otherwise, the more or less shall I be disposed to extend it," wrote Davison. He mentioned that he had also written to Governor Phillip upon the subject. ${ }^{85}$ Davison had a continuing interest in New South Wales: in 1788 he been contracted to send supplies to the colony by HMS Guardian, and in subsequent years also undertook contracts for this purpose ${ }^{86}$ The naval agent on Daedalus, Richard Hergest, was instructed to "put himself under [Vancouver's] direction for the execution of this Service [the restitution of the seized property], in order that Capt. Vancouver may be impeded as little as possible in the progress of his intended Survey": in effect, he was to be the lieutenant-governor of the settlement ${ }^{87}$ Hergest never reached Nootka: he was killed by natives on 11 May 1792 while Daedalus was taking on water at Oahu without their permission. ${ }^{88}$

Vancouver sailed from Falmouth on 1 April 1791 with the expectation of receiving from the Spanish at Nootka Sound title to a large tract of the coast and of forming a settlement to sustain the fur traders. In anticipation of this, prior to arriving at Nootka, on 4 June 1792 (the King's Birthday) he took formal possession at Admiralty Inlet of all the coast and hinterland contiguous to the Strait of Juan de Fuca under the name of New Georgia ${ }^{89}$ Vancouver seems to have performed this act of possession in expectation that the written instructions brought from London by the Daedalus would authorize him to do so, as this had been the tenor of discussions public and private prior to his departure. Those instructions, presumably, would also set out in detail what measures he was to take in making Nootka into a permanent British settlement, who was to be its governor, and so on. He apparently thought he would be ordered to send the Daedalus to Port Jackson after she had unloaded her stores and supplies for the Nootka settlement, where she would take on board a company of time-expired or pardoned convicts to form the initial population of the new settlement, in a manner similar to that set out in the plans drafted in March 1790 for a settlement and survey of the North West coast. In the meantime, William Broughton was to remain in command at Nootka with the Chatham. ${ }^{90}$ The American fur trader, Joseph Ingraham, was present at the time, and recorded in his journal: "We understood it [the Daedalus] was next bound to Botany Bay for convicts to settle the place." ${ }^{.91}$ Ingraham presumably gained this understanding from conversation with Vancouver's officers and crew, if not from Vancouver himself. Vancouver's expectations in

85 Alexander Davison to Thomas Parry, 1 August 1791, British Library, Additional Manuscript 79200, f. 33; cited in Martyn Downer, Nelson's Purse (London: Bantam, 2004), 80.

86 Historical Records of New South Wales, 2: 40; Downer, Nelson's Purse, 80.

87 Dundas to Admiralty, 6 July 1791, Adm 1/4156, no. 50, National Archives, (Kew), quoted in Williams, Enlightenment and Exploration, 43, 48.

88 His place was filled at Nootka by Lt. James Hanson, second in command of the Chatham.

89 Lamb, Vancouver, 569.

90 Ibid., 669.

91 Joseph Ingraham, Joseph Ingraham's Journal of the Brigantine Hope on a Voyage to the Northwest Coast of America, Mark D. Kaplanoff, ed., (Barre, MA: Imprint Society, 1971), 232, 242. 
this respect came to nought when the Spanish commander at Nootka when he arrived there in August 1792, Juan Francisco de la Bodega y Quadra, was able to argue persuasively that the land in question amounted to "little more than a hundred yards in extent any way." 92 Bodega was able to point to the first article of the Anglo-Spanish convention of 28 October 1790, which simply said that: "the Buildings and Tracts of Land, situated on the North West Coast of the continent of North America or on Islands adjacent to that Continent, of which the Subjects of his Britannick Majesty were dispossessed... shall be restored to the said British Subjects." The Daedalus was re-loaded and sent to Port Jackson, and Vancouver and Bodega referred back to their respective governments for clarification of the action to be taken regarding restoration of the site to the British. Vancouver set out his understanding of his government's intentions regarding Nootka in the "Narrative of My Proceedings in His Majesty's Sloop Discovery" he wrote out there on 26 September 1792:

considering the principal object His Majesty had in view in directing the undertaking of this Expedition was for facilitating and requiring commercial advantages, and at one view seeing the importance of this station, situated in the very centre of the commerce of N.W. America... and the nature and quantity of articles of traffic and other stores sent out in the Daedalus, from the Secretary of State's Office, together with such conversation as I had formerly been present at in that office, induced me to believe an establishment was in contemplation shortly to take place some where on this coast, though I had not received a single line from that office on that or any other subject. ${ }^{93}$

The instructions sent to Vancouver on the Daedalus, which reached Nootka in August 1792, simply referred, in the words of the convention, to the restitution of the "Buildings and Tracts of Land... of which the Subjects of his Britannick Majesty were dispossessed." Their imprecision and the confusion created by Bodega's refusal to hand over more than a small parcel of land a hundred yards square at Meares Cove caused Vancouver to send Lieutenant Zachary Mudge back to London on one of the EtchesMeares syndicate's vessels, the Phoenix, to obtain clarification; William Broughton was also subsequently sent back with additional information from Monterey on Spanish ships by way of Mexico, Cuba and Spain. The confusion went back to a change of policy between December 1790, when Nepean prepared the above-quoted first draft of Vancouver's instructions, and the following February, when Home Secretary Grenville drew up a revised version. ${ }^{94}$ By now Grenville was most unwilling to disturb the good relations with Spain that had been reached with the convention of 28 October 1790 settling the dispute over Nootka. Britain and Spain were both beginning to be alarmed at the development of the revolution in France. Consequently, in the instructions Grenville

92 Vancouver to Bodega, 13 September 1792, George Vancouver, “A Narrative of My Proceedings in His Majesty's Sloop Discovery," Report of the Provincial Archives of the Province of British Columbia for the Year ended 1913 (Victoria, BC, 1914), Appendix I, "Papers relating to Nootka Sound and to Captain Vancouver's Expedition," 23; quoted in Warren L. Cook, Flood Tide of Empire: Spain and the Pacific Northwest, 1543-1819 (New Haven: Yale University Press, 1973), 373.

93 Vancouver, “Narrative” (1914), 18; quoted in Cook, Flood Tide of Empire, 367, 388.

94 Instructions dated 11 February 1791, ADM 1/4156: 14 and HO 28/8, ff. 17-24 and HO 28/61, ff. 394, National Archives (Kew); cited in Mackay, In the Wake of Cook, 99, 119. 
drew up for Vancouver on 11 February 1791, maintenance of good relations with the Spanish in the areas he was to visit was given priority, and no mention was made of a British settlement to be made on the coast or of assistance to fur traders. ${ }^{95}$

Grenville became foreign secretary in April 1791, handing over the Home Office to Henry Dundas. In his new office, Grenville strengthened his views about the

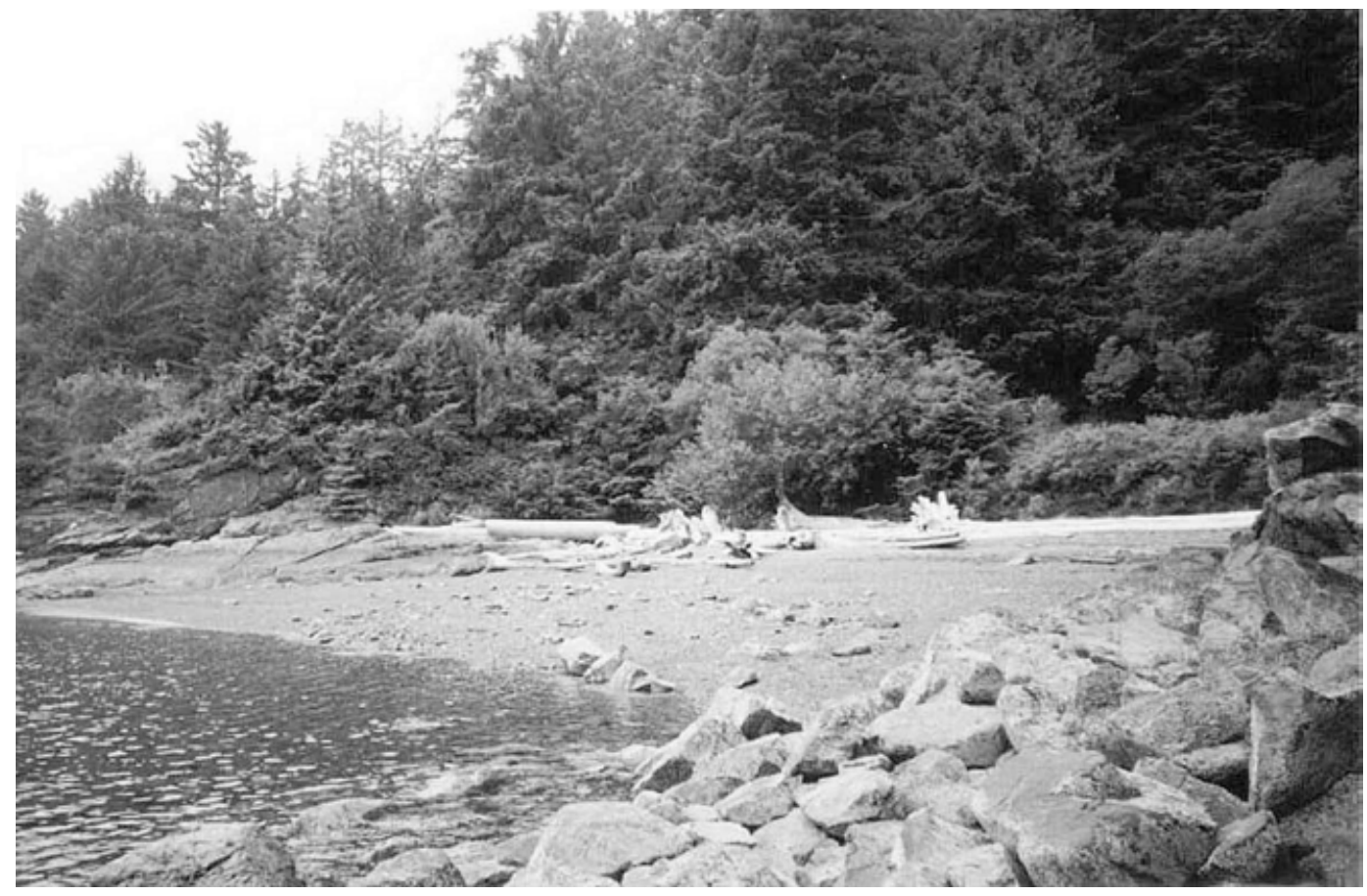

Illustration 2: Meares Cove, Nootka Sound, a parcel of land "little more than a hundred yards in extent any way." Photographed by the author, June 1998.

inadvisability of making settlements in the Pacific which he knew would give offence to Spain. In October 1792, James Colnett was appointed commander of the Rattler for a voyage of exploration in South Atlantic and South East Pacific. When Grenville saw in Colnett's draft instructions drawn up by the Admiralty in November 1792 that he was to take possession of several of the islands he was to survey, and leave men upon them, he warned Dundas's successor as home secretary, Lord Hawkesbury, that the formation of a settlement "would in fact necessarily form such a depot for smuggling with Peru as must drive Spain into a War the first moment she finds it possible." ${ }^{96}$ Hawkesbury consented that no islands should be claimed in the South Seas. Grenville had learned from the Nootka dispute that Spain would take offence at any attempt to make settlements on the western coasts of North or South America and, as foreign secretary, aware of the

95 Instructions dated 10 August 1791, ADM 2/1344 and 3/108: 247, National Archives (Kew); cited in Mackay, In the Wake of Cook, 107, 119.

96 Grenville to Hawkesbury, 23 November 1792, National Archives (Kew), ADM 1/4156; cited in Mackay, In the Wake of Cook, 50, 56. 
imminent likelihood of war with revolutionary France, was most anxious to avoid any action that would "raise useless jealousy," as he put it, on the part of Spain.

William Broughton's arrival back in London was reported in The London Chronicle of 16 July 1793, which noted:

The immediate object of Lieutenant Broughton's coming home, is to acquaint our Government of the conduct of the Spanish Government of Nootka, in regard to the Ratification of the Treaty with Spain. We are sorry to say, that the Governor has wholly refused to comply with the terms of that Treaty in surrendering the district about Nootka. Captain Vancouver was sent out to take possession; and the negociation between him and the Spanish Governor went on very quietly, until the arrival of an American ship there, the Captain of which [Ingraham] persuaded the Governor that the whole stipulation of the Treaty was to cede to the English a small spot; consisting of one hut only, and four old cannon placed about it. This Captain Vancouver refused to accept; and under these circumstances Lieut. Broughton was sent home... We have no doubt but that the Court of Madrid will set this matter perfectly right; at the same time perhaps the whole object is not worth contending for.

Broughton was given command in October 1793 of HMS Providence to return to the Pacific to assist Vancouver. Upon his eventual arrival at Monterey in June 1796 he learned that Vancouver had left the North Pacific homeward bound. Broughton then took the decision in council with his officers to fulfill James Cook's objective of surveying the coast of North East Asia and its adjacent islands from Sakhalin to the mouth of the Nanking River, rather than go south to chart the southwestern coast of South America. He gave the reasons for this decision in his journal, indicating the longevity of Daines Barrington's 1781 recommendation for a survey of Japanese waters:

It should be remembered that, in the third volume of Cook's last work, Captain King observes that the navigation of the seas between Japan and China afforded the largest field for discovery; and the survey of this unknown part of the North Pacific Ocean was particularly recommended by the Honourable Daines Barrington in his Miscellanies, where he says, "The coast of Corea, the Northern part of Japan, and the Lequieux Islands, should also be explored." 97

Broughton's intention was limited to making a hydrographic survey, and apart from Muroran in southern Hokkaido, he entered no Japanese ports. In the southern Ryukyus, he made an involuntary landing on Miyako island, where Providence was wrecked on a reef, and afterwards visited Naha, the port of Okinawa. The pressures of war with France prevented Great Britain from following Broughton's survey with any attempt to open commercial relations with Japan.

\section{James Colnett's Voyage to Japan}

Upon his release in Mexico from Spanish custody following the end of the crisis

97 William Broughton, A Voyage of Discovery to the North Pacific Ocean (London, 1804), iv, 65. Andrew David and Barry M. Gough, eds., William Robert Broughton's Voyage of Discovery to the North Pacific, 1795-1798 (London: Hakluyt Society, 2010). 
between Britain and Spain, James Colnett returned to Macao with the Argonaut and its cargo of furs, where he arrived in May 1791. There he found that the Chinese government had since 13 March imposed a total prohibition on the importation of sea otter pelts, in consequence of a dispute with the Russians (from whose dominions originated, they believed, all the furs traded by Europeans). Colnett and his backers, Cox and Beale, decided to pursue the primary object of the King George's Sound Company, which had been re-affirmed when the partnership had been formed with Meares, "the Opening an intercourse with the Japanese Islands for the Sale of our Furs and American produce." Beale's sailing orders for Colnett stated:

The Prohibition to the Importation of Sea Otter Skins into this Kingdom [China] is an event which no Human Prudence could have foreseen, or guarded against the consequence of. And I hope, whatever may be the ultimate loss to your owners from this unexpected prohibition, that there is not an Individual among them but will rejoice should it become a means of opening a new branch of commerce to their country; and you will have at least a satisfaction in reflecting that you was entrusted with the Command of the only British Vessel that has for this Century visited the Kingdom of Japan for the purpose of opening a trade upon honourable and liberal terms. ${ }^{98}$

Colnett left Macao on 26 July 1791 for Japan. He attempted to make port at Nagato and five other places along the western coast of Kyushu and Honshu, but the Japanese authorities were inflexible in refusing entry. His final attempt to make port was on 17 August, and he recorded his experience in his journal:

As I drew near the Village, discovered an opening which promis'd a Harbour, form'd by an isle. This Inlet I push'd for; but when near the mouth of it a number of Boats came out, and among the rest, two arm'd ones who insisted on my Immediately going to sea. One of the arm'd Boats lay me athwart hawse, as if to cut my Cables If I attempted to anchor; the other remain'd along side, and another lay to at a small distance which I took to arm'd also. I wore as desired, and requested them to let me Anchor. At that time there was 46 fathoms water and a very small distance from the Shore. I informed them by signs I wanted water, and they Supplied me immediately with what they had in their Boats. But to my other entreaties shut their Eyes and Stopt their Ears, by which I understood their Orders were to be both deaf and Blind, to all I could say... having been at Anchor at Six different places on the Coast of Japan, without any prospect of Communication of Trade with the Natives, but by force of Arms which in my present situation, man'd and arm'd as I was, I did not think proper to attempt but to make one more effort to open a new commerce by trying the Coast of Corea. ${ }^{99}$

Colnett had come to the view that an official embassy from the British to the Japanese government was required to open commercial relations, as he subsequently wrote:

all Nations improve by commerce which I have every reason to believe will soon be extinded to Corea and Japon where a great Call for furs will happen, when at Corea and

98 F.W. Howay, ed., The Journal of Captain James Colnett aboard the Argonaut (Toronto: Champlain Society, 1940), 234-9. 
Japon myself I found that aversion to Europeans greatly diminished, which had existed since that dreadfull massacre in 1622 when Europeans of all Nations except Holland were put to death... an Embassy to Japon [sic] might open that trade much sooner than is believed. ${ }^{100}$

\section{George Macartney's Embassy}

The failure of Colnett to gain admission to Japan in 1791 marked the end of attempts by British private merchants to seek entry to that market. The Etches-Meares consortium sent no more ships, and devoted their efforts to an attempt, ultimately unsuccessful, to obtain compensation for their losses from the Spanish government. John Henry Cox, Meares's sponsor, died at Canton or Macao in October 1791. Alexander Dalrymple, who had been given information on the North Pacific fur trade by Cox, added his voice to the call for an embassy to Japan in a memorandum dated 23 February 1791:"There is indeed great reason to suppose a beneficial intercourse might be opened with Japan... yet is it likely that an illiterate adventurer in a chance ship should be the most proper person to renew our intercourse with a people so scientific and well informed?"101

On 26 September 1792, Lord Macartney sailed from Portsmouth on an embassy to China, with the intention of subsequently proceeding to Japan. The memorandum quoted above written in Calcutta in 1788 urging, on the basis of advice from Isaac Titsingh, that the projected British embassy to China also be sent to Japan was given to Macartney together with all the other documentation prepared for Cathcart's embassy, and the ideas expressed in it, which confirmed suggestions made by Macartney himself to Dundas, were incorporated in his instructions, which read:

It is possible that you may find it either necessary or expedient to touch upon the Coast of Japan. That Country produces Tea as good as, and probably cheaper than, that of China. The difficulties of trading there, which have so long deterred other nations from attempting it, are now said to be almost ceased. ${ }^{102}$

Macartney's ambassadorial instructions were signed by Secretary of State Henry Dundas on 8 September 1792, and included letters of credence from George III to the

100 "A Voyage for Whaling and Discovery Round C. Horn into the Pacific Oceans made under Protection of the Rt. Hon. Lords Commissioners of the Admiralty, Performed in the Merchant Ship Rattler by J. Colnett, Lieut. in the R.N., 1793 and 1794," Br. Lib., Add. MS 30,369, p. 390 (f. 251); cited in Barry M. Gough, The Northwest Coast: British Navigation, Trade, and Discoveries to 1812 (Vancouver: UBC Press, 1992), 196-7.

101 Memorandum on Trade to the South Seas and the North West Coast of America, British Library, India Office Records and Archives, Home Miscellaneous, 494/5, pp. 441 ff. Quoted in Harlow and Madden, British Colonial Developments, 39.

102 Henry Dundas, Instructions to Lord Macartney, 8 September 1792, British Library, India Office Records and Archives, Factory Records, China, G/12/91, 341ff.; quoted in Harlow and Madden, British Colonial Developments, 48; Macartney to Dundas, 4 January 1792, British Library, India Office Records and Archives, Factory Records, China, G/12/91, f. 37; cited in Harlow, The Founding of the Second British Empire, 2: 569. 
emperor of Japan, to be executed after completing his mission to China. The letters of credence stated that he had been sent "for the purpose of cultivating a mutual intercourse and friendship, and for the purpose of entering upon treaties of commerce mutually agreable to our peoples." 103

Joseph Banks was closely involved in the organisation of the embassy, both as president of the Royal Society and as a member of the Privy Council for Trade and Plantations. He also provided the embassy with a "Note relative to the method of bringing to England seeds from China \& Japan in a state of vegetation," and "A list of curious plants, natives of China and Japan, wished to be obtained from thence"; together with copies of his recently published Icones selectae Plantarum quae in Japonia collegit et delineavit Engelbertus Kaempfer. ${ }^{104}$ Attempts were made to find a Japanese interpreter, which included Secretary of State William Grenville writing to the British ambassador to St. Petersburg, Charles Whitworth, about a Japanese castaway who was reported to be in Russian hands: this was the shipwrecked merchant, Daikokuya Kodaiyu 大黑屋光太夫, who had been met in Nizhni Kamchatsk by Barthélemy de Lesseps, the Russian language interpreter with the Lapérouse expedition, who was conveying the journal of Lapérouse from Petropavlovsk to Paris. ${ }^{105}$ The Russians prevented any access to Daikokuya by the British when he was brought to St. Petersburg, and used him themselves as an interpreter in 1792 during the expedition to Japan led by Adam Laxman, as reported by The Morning Chronicle of 28 April 1794:

A new channel of commerce has been proposed between the Japanese and the Russians, by a person from Japan who was shipwrecked on the Russian coast some years since, but returned home with the son of the Professor Laxman. He is now charged with a kind of treaty to the Japanese, promising to send a ship to Russia every year; but the want of ship-timber in Kamschatka is supposed to be a drawback upon this undertaking.

The Japanese government did respond to Laxman's visit to Nemuro and Matsumae in Yezo (Hokkaido) by agreeing to receive a Russian ambassador through the port of Nagasaki. Circumstances prevented Russia from sending an ambassador until 1804, when Adam von Krusenstern's expedition to the North Pacific carried an ambassador to Nagasaki, who upon arrival there was refused admission. ${ }^{106}$

Upon reaching Tientsin in July 1793, Macartney gave instructions to Captain Sir Erasmus Gower, commanding HMS Lion, which carried the embassy, for a reconnoitring voyage to Japan. Gower was to proceed to Edo, where he was to deliver a letter to the "Cubo, or Temporal Sovereign of that Country" (公方 i.e. the Shogun). Nautical

103 Public Record Office of Northern Ireland, Macartney Papers, D/2731/3 and D2731/4.

104 Carter, 293.

105 Travels in Kamchatka (London, 1790), 208-17. Whitworth to Grenville, 18 May 1792 with enclosure no.2, Wason Collection, Cornell University, docs. nos. 119 and 359, quoted in J.L. Cranmer-Byng, "Russian and British Interests in the Far East, 1791-1793," Canadian Slavonic Papers X (1968), 357-75.

106 A. J. von Krusenstern, Voyage round the World, Richard Belgrave Hoppner, trans. (London: John Murray, 1813). 
observations were to be made and the opportunity taken of observing how far Japanese needs might lead them to purchase any British manufactures and whether in that case the country afforded any primary products (apart from copper) which might profitably be imported into England. Gower would soon be able to ascertain whether the Japanese entertained that marked aversion to all foreigners which had been attributed to them formerly by persons "who might indeed have been influenced in their accounts by a desire of deterring us." The failure to find in Europe a Japanese interpreter for the language would make it difficult for Gower to conduct specific negotiations with that court, but for the purpose of this preliminary encounter three individuals were being sent who spoke Chinese and Malay. As soon as a reply was received from the Japanese sovereign, or if no reply had come after a fortnight, Gower was to sail for Manila, where he might find some individuals who had been to Japan and had learned the language. If the services of such a person could be secured Macartney was ready to pay him handsomely: he would be "a vast acquisition in the event of my going to execute my commission of Embassador to the Emperor of Japan." 107

Circumstances prevented Macartney from acting on the recommendation to proceed to Japan following his visit to China in $1793 .{ }^{108}$ Gower's crew were too sick to undertake the voyage to Japan and the Philippines before Macartney rejoined the ships at Canton on 19 December 1793. From Canton, he wrote to Dundas on 23 December expressing his continuing belief in the desirability of a mission to Japan:

Japan appears the only place capable of supplying Tea to any considerable amount in case of failure in the quantity or exorbitancy in the price of that article from China, until we can have plantations of it in Bengal. In the meantime the expediency of attempting an intercourse with the Japanese subsists in its full force. Tho from the conversations I had at Batavia with a Dutch Gentleman of a very liberal disposition who was several years resident in Japan [Isaac Titsingh], I collected nothing that could induce me to depend on a favorable reception there, I learned nothing to deter me from the trial. The risk would, at least, be personal, as we have hitherto there no trade to lose. And no moment, if any, could be so propitious for opening up a new trade with them, as when, from the present general confusion of affairs of the Dutch East India Company, their connexion with the Japanese is greatly on the decline. ${ }^{109}$

His hopes of being able to proceed to Japan were ended by the confirmation at Canton of the news he had received in Peking of the outbreak of war with France the previous February, and consequently of the vulnerability of his ships to attack by French cruisers operating from Batavia. He also received there a letter written from Batavia on 4 November 1793 by Isaac Titsingh. ${ }^{110}$ A change in the Shogun's

107 India Office, Factory Records, China, G/12/92, pp.137-50; published in Sir George Staunton, An Authentic Account of an Embassy from the King of Great Britain to the Emperor of China (Philadelphia, 1799), 250-1.

108 Helen H. Robbins, Our First Ambassador to China (London, Murray, 1908), 380.

109 Macartney to Dundas, 23 December 1793, India Office, Factory Records, China, 1084 $\mathrm{G} / 12 / 20$

110 Titsingh to Macartney, 4 November 1793, Appendix to Macartney's Journal, Toyo Bunko (Tokyo); cited in Cranmer-Byng, An Embassy to China; Alistair Lamb, "Lord Macartney in 
administration, together with the failure of the rice crop over successive years throughout Japan and consequent famine, rendered the timing for a voyage of commercial diplomacy to that country unpropitious. On 23 December, Macartney recorded his conclusion in his journal: "I have given up my projected visit to Japan, which (though now less alluring in prospect) has always been with me a favourite adventure as a possible opening of a new mine for the exercise of our industry and the purchase of our manufactures."111

\section{The unattainable object}

The optimistic expectations entertained by British merchants and statesmen regarding the Japanese market were based, as John Meares said, on "some imperfect Knowledge." This related in particular to the trade which they understood to be carried on with Japan through the Kurils in the north and the Ryukyus in the south. The evolving state of affairs in Japan meant that this knowledge was much out of date by the time it was acted upon. It was obtained almost entirely from Dejima, the keyhole in the door through which Europeans peered for glimpses of Japan. The situation in the northernmost reaches of the Japanese empire was similar in some respects to that in the Ryukyus, insomuch as the tenuous sway the Tokugawa Shogunate exercised over the Daimyo of Matsumae, who controlled Yezo (Hokkaido) and adjacent islands, allowed the latter to carry on a clandestine trade with the Russians in the Kuril Islands and with the Chinese through Sakhalin. Although Matsumae made strenuous efforts to hide this trade from the government at Edo, knowledge of it did leak out. When he became aware of its importance, the reaction of Tanuma Okitsugu, the chief minister of the Shogun Ieharu from 1760 to 1786, was to see the approach of the Russians from Kamchatka along the Kurils as an opportunity to relax the closed country policy which had been followed since 1639, and to begin to develop foreign trade. In pursuance of this policy, in 1785 Tanuma sent a commission of inquiry to investigate at first hand conditions in Yezo, the Kurils and Sakhalin. Tanuma also promoted an expansion of the trade with the Dutch at Dejima, and allowed freer contact between the Dutch merchants there and Japanese scholars. Isaac Titsingh and Carl Thunberg, whose stays in Japan coincided with this period of apparently growing openness, were the sources of English optimism regarding trade with Japan.

Conditions in Japan changed greatly after Titsingh's departure from the country. In 1783 the volcano of Mount Asama erupted, with catastrophic effects on the climate, leading to a failure of crops and widespread famine (remembered as one of the worst in Japan's history). Tanuma's reformist government was blamed for the natural disasters and famine. His rivals were powerful, for he had risen against the odds from the lowest ranks of the samurai to the highest offices through the personal favour of the Shogun. The death of the Shogun Ieharu in 1786 meant the downfall of Tanuma and his replacement by Matsudaira Sadanobu, a member of a collateral branch of the Tokugawa family and a firm believer in the time-sanctioned policies of his ancestors. Tanuma's policies were comprehensively repudiated, including his plans for trade with the Russians in the

\section{Batavia, March 1793," Journal of the South Seas Society XIV (December 1958), 57-68.}


northern islands. The Dutch trade at Dejima was restricted to one ship a year, and personal contacts between the Dutch and Japanese were again prohibited under severe penalties. These events were the "Commotions" referred to by Richard Etches in his letter to Banks of 8 August 1788. The Sadanobu regime viewed the increasing presence of foreign ships off the coasts of Japan with alarm, and in September 1791, following Colnett's attempts to make port in western Japan, issued a new law which, referring to "strange ships which have in recent years been appearing and disappearing off the coasts of Chikuzen (northern Kyushu), Nagato and Iwami”, ordered the repelling of all foreign ships. $^{112}$ It seemed for a moment, when the Russian emissary Adam Laxman arrived at Matsumae with the repatriated Kodaiyu in October 1792, that the Sadanobu administration might have been willing to open the door wider at Nagasaki, but the opportunity was lost when Russia was unable respond promptly to the invitation to send an embassy there. ${ }^{113}$ The policy of seclusion was thus reimposed in full vigour, and was to remain in place until United States Commodore Mathew Perry's "black ships" forced its abandonment in 1853.

In a convention signed in Madrid on 11 January 1794, Spain and Britain agreed that both powers should abandon Nootka forever. Henry Pearce, a lieutenant of the Royal Marines, was sent to Nootka, and his report on the actions carried out there in fulfilment of the terms of the convention was published in The European Magazine for October 1795:

I proceeded from Monterrey to Nootka, in company with Brigadier-General Alava, the Officer appointed on the part of the Court of Spain, for finally terminating the negotiations relative to that Port; where, having satisfied myself respecting the state of the country, at the time of the arrival of the Spaniards, preparations were immediately made for dismantling the Fort, which the Spaniards had erected on an Island that guarded the Mouth of the Harbour, and embarking the Ordnance. By the morning of the 28th [of March 1795], all the Artillery were embarked; part on board of His Catholic Majesty's Sloop of War Activo, and part on board the San Carlos Guard Ship. Brigadier-General Alava and myself then met, agreeably to our respective instructions, on the place where formerly the British building stood, where we signed and exchanged the Declaration and

112 Donald Keene, The Japanese Discovery of Europe, 1720-1830 (Stanford: Stanford UP, 1969); Herman Ooms, Charismatic Bureaucrat: A Political Biography of Matsudaira Sadanobu, 1758-1829 (Chicago: University of Chicago Press, 1975); George Alexandr Lensen, The Russian Push toward Japan: Russo-Japanese Relations, 1697-1875 (Princeton: Princeton UP, 1959); John Whitney Hall, Tanuma Okitsugu, 1719-1788: Forerunner of Modern Japan (Cambridge: Harvard UP, 1955); Shinmura, Izuru, “Tenmei Jidai no Kaigai Chishiki (Overseas Knowledge of the Tenmei Era)," Shinmura Izuru Senshu (Kyoto, 1943); Isaac Titsingh, Memoires et anecdotes sur la dynastie regnante des Dhogouns, souverains du Japon (Paris: A. Remusat, Nepveu, 1820), published in English as Illustrations of Japan (London, 1822).

113 Yasushi Inoueì, Rêves de Russie, Brigitte Koyama-Richard, trans. (Paris: Pheìbus, 2005); Kisaki, Ryohei, Kodaiyu to Lakusuman: Bakumatsu Nichi-Ro Kosho no Isshokumen/(Kodaiyu and Laxman: An Aspect of Japanese-Russian Relations in the Late Edo Period (Tokyo: Tosui Shobo, 1992). 
Counter-Declaration for restoring those lands to his Majesty, as agreed upon by the two Courts. After which ceremony, I ordered the British Flag to be hoisted in token of possession, and the General gave directions for the troops to embark.

The ceremonial mutual withdrawal from Nootka took place ten years after Etches and Banks had first discussed their grand plan. The ten years of effort had failed in the main aims of establishing a permanent base for British fur traders on the North West coast and of using furs to open trade with Japan. This failure deprived the colony established in New South Wales in 1788 of the opportunity to fulfil the expectations held for it that it would support and benefit from such trade. Although the trade in seal skins and furs obtained from the Southern Ocean became the first important export industry of the New South Wales colony, the market for this trade was China through Canton, not Japan. ${ }^{114}$ The French Revolutionary and Napoleonic Wars absorbed the attention of Great Britain, France, Russia and Spain after 1793 and delayed the opening of commercial relations with Japan for another half-century, a development that was then led by the United States of America.

114 Steven, Trade, Tactics and Territory, Chapter 5, “"The Pursuers of Peltry': the Pacific sealing industry," pp. 85-105. 


\title{
CNRS 2009 Conference and AGM \\ in association with Dalhousie University CFPS Maritime Conference \\ The Canadian Navy Yesterday, Today and Tomorrow - The ships, the sailors, their equipment and what they did
}

\author{
Halifax - 16 - 19 June 2010
}

The Society is pleased to hold its 2010 Conference and Annual General Meeting at the famous Pier 21 on the Halifax waterfront, in association with the Centre for Foreign Policy Studies (CFPS) of Dalhousie University.

This conference has been integrated into the Canadian Navy's centennial celebration events and also coincides with the $70^{\text {th }}$ anniversary of the Canadian naval Research \& Development community; as a result, that community is a major contributor to the conference. The conference also commemorates Dalhousie's long association with the Navy, especially the Centre for Foreign Policy's direct, 40-year relationship with the Navy. The Canadian Nautical Research Society (CNRS) will hold its annual general meeting in Halifax at the same time and an additional day will be given over to other topics of more general interest to Society members. covering:

There will be three, one-day sessions Wednesday-Friday 16-18 June inclusive

(1) ships and people;

(2) equipment (systems), and operations (including training); and

(3) future challenges and possible technological responses.

A fourth one-day session will be set aside on Saturday 19 June for Society business and papers on other topics of interest to CNRS members.

There will be an evening reception at the Maritime Museum of the Atlantic on Wednesday 16 June and a conference dinner in the evening of Thursday 17 June. A tour to the Fisheries Museum of the Atlantic in Lunenberg <http://museum.gov.ns.ca/fma/ $>$ is being considered for Friday 18 June for Society members in lieu of the future challenges session but at extra cost to be determined.

Paper proposals are invited for submission to the conference organizers; e-mail Peter Haydon at <navalconference@eastlink.ca> and/or Richard Gimblett at <richard.gimblett@forces.gc.ca> no later than 31 March 2010. Applications for the Gerry Panting New Scholar's Award can be similarly directed. Accepted papers will be considered for publication with first right of refusal by CNRS-CFPS.

A block of rooms is reserved at the conveniently co-located Westin Hotel at a preferential conference rate of $\$ 175$ per night; other accommodation options can be investigated at: $<$ http://visitors.halifax.ca/accommodations.shtml $>$.

Further information about the conference can be obtained from the Centre for Foreign Policy Studies' website $<$ http://centreforforeignpolicystudies.dal.ca/index.php $>$ or by direct e-mail enquiry to the organizer, Peter Haydon, at <navalconference@eastlink.ca>. 